2014

\title{
The Origin of Parental Rights: Labor, Intent, and Fathers
}

Dara Purvis

Penn State Law

Follow this and additional works at: http://elibrary.law.psu.edu/fac_works

Part of the Family Law Commons

\section{Recommended Citation}

Dara Purvis, The Origin of Parental Rights: Labor, Intent, and Fathers, 41 Fla. St. U. L. Rev. 645 (2014).

This Article is brought to you for free and open access by the Faculty Works at Penn State Law eLibrary. It has been accepted for inclusion in Journal Articles by an authorized administrator of Penn State Law eLibrary. For more information, please contact ram6023@psu.edu. 


\title{
THE ORIGIN OF PARENTAL RIGHTS: LABOR, INTENT, AND FATHERS
}

\author{
DARA E. PURVIS *
}

\begin{abstract}
Most theories of parentage fail to explain the genesis of the right to parent-for example, why does a biological relationship generate parental rights? This Article shows that the law of parental rights mirrors theories of acquiring property, and that the law has shifted over time, from favoring a property right based in genetics to a Lockean theory of property rights earned through labor. The growth of Lockean labor-based theories is epitomized in reforms to parentage laws that incorporate functional theories of parenting, meaning that adults who perform caretaking work that creates a significant relationship with children are recognized as legal parents, even if they are not genetically related to the child. A laborbased understanding of parentage may even reach to gestational work performed by the pregnant woman.

This Lockean labor-based theory, however, poses a challenge to male parental rights, because men have fewer opportunities to contribute labor for the benefit of the child. This disparity is heightened in the context of unwed biological fathers, who must create a signifi. cant relationship with the child before gaining constitutional parental rights. This Article argues that intent to be a father, as demonstrated through behavior preparing for a child's arrival, should be incorporated into labor-based theories of parentage. Including an intentbased approach will thus address a gendered inequality in existing parental law.
\end{abstract}

I. INTRODUCTION.

II. ACQUISITION OF PARENTAL STATUS AS PROPERTY.

A. Parental Status as Bodily Unity.

B. The Growth of Labor-Based Theories .................................................... 654

C. Case Study: The Marital Presumption .................................................... 661

III. FATHERHOOD AS LABOR ............................................................................. 663

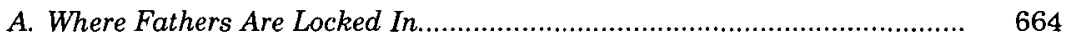

B. Exceptions to the Biological Rule........................................................... 667

C. Unwed Biological Fathers and the Supreme Court.................................. 669

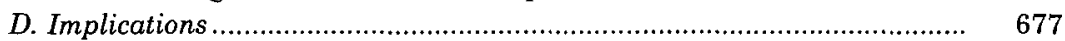

IV. LABOR-BASED THEORIES INTO DOCTRINE................................................... 680

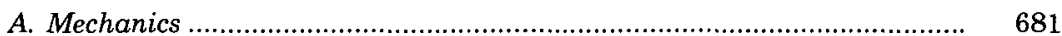

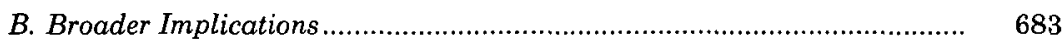

1. Married Biological Fathers............................................................. 683

2. Wider Applications: Intent-Based Parentage..................................... 684

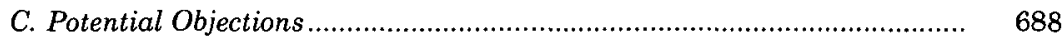

1. Feminist Objections....................................................................... 688

2. Criticisms of Prebirth Labor ........................................................ 692

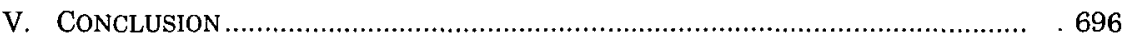

* Assistant Professor, Penn State Dickinson School of Law; Yale Law School, J.D.; University of Cambridge, M.Phil.; University of Southern California, B.A. I am deeply appreciative for thoughtful comments from Kerry Abrams, Kenworthey Bilz, Mary Patricia Byrn, Devon Carbado, June Carbone, Dan Hamilton, Paul Heald, Jennifer Hendricks, Patrick Keenan, Alicia Brokars Kelly, Laurie Kohn, Robert M. Lawless, Beth Burkstrand Reid, Victor Romero, Carol Rose, Arden Rowell, Jamelle Sharpe, Kate Stith, Melissa Was. serman, and Lesley Wexler, as well as feedback from participants at the Emerging Family Law Scholars conference, the International Society of Family Law meeting, and the AALS New Voices in Gender Studies panel. 


\section{INTRODUCTION}

Jonathan and Lorraine are the biological parents of Jessica. When Jessica was born, Jonathan visited the two in the hospital every day until they were discharged. Rather than return to the home she had shared for two years with Jonathan, however, Lorraine moved elsewhere and did not tell Jonathan where she and Jessica had gone. For about one year, Jonathan was occasionally able to find Lorraine, and when she allowed him to do so, he visited Jessica. Eventually Jonathan hired a private detective to find Lorraine, who by that time had married another man who had legally adopted Jessica, meaning that Jonathan was now a legal stranger to his biological daughter. Lorraine said he could not visit Jessica, and if he tried to do so she would have him arrested.

Jonathan attempted to assert his rights as a parent in court, challenging Jessica's adoption and seeking to be recognized as her legal father. Although he advanced his case to the Supreme Court, ${ }^{1}{ }^{\text {Jona- }}$ than Lehr was unsuccessful in his efforts to be identified as Jessica's father. ${ }^{2}$ Rejecting his argument that his fundamental rights as a parent were violated when Jessica was adopted without his permission or knowledge, ${ }^{3}$ the Court held that unwed biological fathers do not have constitutional rights as parents until they take on parental responsibilities and create a substantial relationship with their biological child. ${ }^{4}$ If they are unable to do so-in the case of Jonathan Lehr, even if they are prevented from doing so by another party-states are free to enact laws that do not recognize them as legal parents. ${ }^{5}$ Although most jurisdictions currently provide unwed biological fathers with methods to assert their paternity, such fathers must satisfy specific procedural requirements and in some circumstances can be blocked from asserting their paternity as Jonathan Lehr was. ${ }^{6}$ Such biological fathers are thus legal strangers to their child and can be absolutely barred from even asking for custody or visitation with the child.

By contrast, biological mothers are uniformly identified by state law as legal parents. ${ }^{7}$ There is thus a stark difference in the statutory

1. Lehr v. Robertson, 463 U.S. 248 (1983).

2. Id. at 267-68.

3. Id. at 265 .

4. Id. at 261-62.

5. See id. at 262 . It is worth noting that the Lehr opinions do not give an explanation as to why the mother wished to keep Lehr from his biological child.

6. James G. Dwyer, A Taxonomy of Children's Existing Rights in State Decision Making About Their Relationships, 11 WM. \& MARY BILL RTS. J. 845, 865-81 (2003).

7. Id. at 859-60. 
and constitutional interests of biological mothers and fathers. ${ }^{8}$ The Supreme Court, however, has repeatedly rejected equal protection claims arguing that it is unconstitutional to use separate rules turning on the biological parents' gender. ${ }^{9}$

The different treatment of biological mothers and fathers raises two troubling sets of issues, both theoretical and doctrinal. First, making it more difficult for otherwise similarly situated mothers and fathers to secure status as legal parent seems problematically consonant with stereotypes that women are better or more natural parents than men. Second, divergent requirements placed on biological parents obscures the significance of biology as a doctrinal rule. Genetic relationships are often where the process of identifying legal parents starts, and in many circumstances genetics are alone sufficient to determine legal parentage.$^{10}$ In the context of unmarried biological fathers, however, biology is generally both necessary and sufficient for the purpose of imposing a child support obligation, yet it is necessary but not sufficient if the biological father seeks parental rights. ${ }^{11}$ Not only is this at least superficially inconsistent, but the additional burden placed upon unwed biological fathers indicates that the theory underlying how parentage is acquired has not yet been answered. If a biological relationship is not always a trigger for recognition as a legal parent, then why is it ever a trigger? It seems intuitive that the genetic parents of a child are where analysis should start, but why does the genetic relationship generate parental rights?

This Article begins with that question-how are parental rights acquired?-as a stepping-off point to explain the law as it exists today and to propose doctrinal reforms creating a more unified parentage regime. I argue that the law of parental rights mirrors theories of acquiring property, and that the law has shifted over time, from favoring a property right based in genetics to a Lockean theory of property rights earned through labor. This analysis has both descriptive and normative value, showing that the current constitutional understanding of fatherhood is both inconsistent and gendered. A growing understanding of parentage as created through labor helps to explain the law's current treatment of fathers, particularly unwed biological fathers. It also points to a specific doctrinal amendment: understand-

8. As will be discussed further below, adjudications of the constitutional rights of unwed biological fathers have arisen in the context of challenges to state laws that do not recognize such men as legal fathers. For obvious reasons, biological mothers have not brought similar challenges, as they are consistently identified as legal mothers by state law. Descriptions of the constitutional interests of biological mothers have thus generally appeared in suits brought by unwed biological fathers, often contrasting the two.

9. See Nguyen v. INS, 533 U.S. 53, 64-65, 68 (2001); Lehr, 463 U.S. at 265-68; Parham v. Hughes, 441 U.S. 347,356 (1979).

10. See infra Part II.A.

11. See infra Part III.C. 
ing prebirth parental labor by unwed biological fathers as fulfilling the constitutional requirement that an unwed biological father create a substantial relationship with his child before his status as parent accrues constitutional rights. In my proposed substantial prebirth labor test, labor is evaluated as a demonstration of intent, addressing some of the traditional criticisms of intent-based theories as well as generating broader possibilities for incorporating labor-based uses of intent in parentage law.

In Part II, I explain my account of the acquisition of parental status as analogous to the acquisition of property, explaining a move from parentage as bodily unity to the increasing strength of laborbased theories of parentage. Part III addresses fatherhood as labor: where fatherhood is imposed and withheld and the treatment of the constitutional parental rights of unwed biological fathers. Part IV proposes treating the intent to parent, as demonstrated in prebirth labor by unwed biological fathers, as satisfying the requirement that an unwed biological father have a substantial relationship with his child before his parental status exists as a constitutional matter. I also suggest expansions of the labor-based theory of intent beyond the context of unwed biological fathers to include postbirth labor, married biological fathers, same-sex couples, and expanding the number of legal parents to more than two.

\section{ACQUISITION OF PARENTAL STATUS AS PROPERTY}

There is a deep assumption-underlined by strong rules of parentage, such as the biological relationship and the marital presumption-that biological parents are natural parents, and any other rules of parentage are the operation of law. This is understandable, as the default presumption (that the legal mother and father of a child will be the woman who gives birth to the child and that woman's husband) was universally adopted in state law. ${ }^{12}$ This default presumption matches the historically most common model of parentage, ${ }^{13}$ where state intervention is least likely and therefore most invisible. ${ }^{14}$ Indeed, in most families, the determination of legal parentage is not disputed. ${ }^{15}$ This understanding of natural parents as real or inherent parents "view[s] parentage statutes as recognizing an inherent rela-

12. See Mary Patricia Byrn \& Jenni Vainik Ives, Which Came First the Parent or the Child?, 62 RUTGERS L. REV. 305, 318-19 (2010).

13. Children born to married parents may soon be the minority of births: in 2008 , forty-one percent of children were born to unmarried parents. Hannah Alsgaard, Decoupling Marriage \& Procreation: A Feminist Argument for Same-Sex Marriage, 27 BERKELEY J. GENDER L. \& JUST. 307, 308-09 (2012).

14. See Byrn \& Ives, supra note 12 , at 318.

15. Emily Buss, Essay, "Parental" Rights, 88 VA. L. REV. 635, 650 (2002). 
tionship between an adult and a child, or as a means of guaranteeing an adult's pre-existing constitutional right to raise a child." 16

Reliance on an inherent natural right of parenthood is uncomplicated, and much of the time it is an accurate heuristic. The vast majority of the time, parentage law invisibly supports uncomplicated relationships: a baby is born at a hospital to a woman whose male partner is on hand and joyfully identifies himself as father. In such a context, parental status is not contested, and there is no formal legal proceeding to adjudicate paternity. Even though there is no proceeding to formalize the status of the assumed mother and father, however, the roles come with significant legal freight.

Once the status of legal parent is recognized, it is a profoundly powerful position. The legal rights of parenting, often summarized as "care, custody, and control" over one's children, were described by Justice O'Connor in Troxel $v$. Granville as "perhaps the oldest of the fundamental liberty interests recognized by this Court."17 Vindication of the rights of parents to decide how to raise their children, even if their decisions ran counter to community preferences, formed the first seeds of the fundamental rights later explicitly protected in the Court's right-to-privacy jurisprudence. ${ }^{18}$

A key element of the care, custody, and control of one's children is the ability to exclude-a parent may choose what people are not allowed around their children. This parental right is particularly significant in the context of disputes regarding other people who might function or even see themselves as parents. Troxel presented the example of grandparents seeking to continue visits with their grandchild against the wishes of one parent. ${ }^{19}$ The case arose after Tommie Granville and Brad Troxel, who had two children together, broke up. ${ }^{20}$ Troxel moved in with his parents and regularly brought his daughters home with him on the weekends. ${ }^{21}$ After Troxel's suicide, Granville began to decrease the frequency of visits between the children and their paternal grandparents. ${ }^{22}$ After unsuccessfully appealing to Granville, the grandparents filed a lawsuit under a Washing-

16. Byrn \& Ives, supra note 12 , at 308 .

17. Troxel v. Granville, 530 U.S. 57, 65 (2000).

18. See, e.g., Pierce v. Society of Sisters, 268 U.S. 510, 534-35 (1925) (holding that a statute requiring public school enrollment unconstitutionally and "unreasonably interfere[d] with the liberty of parents . . . to direct the upbringing and education of children under their control"); see also Meyer v. Nebraska, 262 U.S. 390, 399-400 (1923) (holding that a statute barring foreign language instruction unconstitutionally violated parents' liberty interests).

19. Troxel, 530 U.S. at 60-61.

20. Id. at 60 .

21. Id.

22. Id. at $60-61$ 
ton statute allowing " '[a]ny person'" to petition state courts for visitation rights, which could be granted " when visitation may serve the best interest of the child." "23 For obvious reasons, the Troxels were a sympathetic pair: they had helped their son care for the children, had built a close relationship with the children through regular visits over a period of years, and undoubtedly the love they already felt for the girls was magnified by the tragic loss of their son. From the perspective of the children, moreover, the Washington Superior Court found that it was in the daughters' best interests that the court order substantial visitation with their grandparents. ${ }^{24}$ After a series of appeals, however, the Supreme Court held that the court order "unconstitutional[y] infring[ed] on Granville's fundamental right to make decisions concerning the care, custody, and control of her [children]." ${ }^{25}$ So long as a legal parent has not been found to be unfit, therefore, his or her decisions regarding other adults allowed to have contact with the child cannot be second-guessed by a court, even if the court finds that the legal parent's decisions are not in the best interest of the child.

The impact of strong parental rights in determinations of parentage is thus large, as the legal parent has the constitutional ability to shut other potential parents out of the child's life. For example, what if the husband of a woman who gives birth and believes at the time that the child is his biological child later finds out that is not the case? What if a second man comes to the hospital and identifies himself as the sperm donor? What if five years later, the mother's boy. friend who has helped to raise the child wants his relationship legally recognized? In all three examples, the mother's role as legal parent is unchallenged, but the three men-who in two examples already have a parental relationship with the child-are in more precarious positions. Moreover, a court confronted with such cases cannot, perverse as it may seem, begin to resolve the dispute by asking what result is in the best interest of the child. As explained above, evaluations of the best interest of the child are, as a constitutional matter, set aside in favor of the decisions of a legal parent who has not been found to be unfit. In disputes as to parentage, courts must therefore resolve legal parentage first, regardless of whether it would be better for the child to remain in the care of a third party. ${ }^{26}$

23. Id. at 61 (quoting WASH. REV. CODE $§ 26.10 .160(3)$ (1994)).

24. It is worth making clear that Granville did not seek to terminate visitation altogether. The grandparents requested that the children stay with them for two weekends per month plus two weeks each summer. Granville proposed one day per month. The Superior Court ordered one weekend per month, one week each summer, plus a four-hour visit on the grandparents' birthdays. Id.

25. Id. at 72 .

26. See John Lawrence Hill, What Does It Mean to Be a "Parent"? The Claims of Biology as the Basis for Parental Rights, 66 N.Y.U. L. REv. 353, 363 (1991). 
To the extent that the interests of the child are considered in such disputes, therefore, they are taken into account only in unspoken assumptions that the persons identified by the law as legal parents are the persons who will be the best caretakers for the child. ${ }^{27}$ Parentage statutes, however, do not give explanations of why certain people will do a good job in that role. Such judgments rely on unspoken assumptions regarding how parental status is generated. In other words, parentage laws "implicitly appeal to some preanalytic concept of parenthood." 28 These preanalytic concepts of parenthood, however, have been left relatively unexplored. For example, although most people would agree that a biological relationship generates parental status, it is unclear what the justification or theory behind that belief is. ${ }^{29}$

To begin to answer this question, one can look to the parent-child relationship more broadly - to what other legal relationships might it be compared? One common comparison in the relationship of parent to child is to a property right: that is $m y$ child, just as that is $m y$ house. Treating children as property in everyday life now seems archaic, which is accurate in the sense that the analogy's accuracy improves as analysis moves backward in time. To cherry pick an ancient and extreme example, in England during the tenth century, fathers could legally kill children who were young enough to exclusively breastfeed and were free to sell children younger than seven years old into slavery. ${ }^{30}$ Although such literal control over life and death was no longer considered part of the parent's bundle of sticks past the tenth century, children were still viewed as valuable assets that their fathers had the right to control-"children as chattel." ${ }^{31} \mathrm{Fa}$. thers-at this point in time, the law pointedly excluded mothers from legal parental power-had a right to absolute control over their children ${ }^{32}$ In this notion of parenthood, children were an integral part of the family unit's subsistence, particularly in preindustrial American society when the labor of one's children was necessary for a family's

27. See Dara E. Purvis, Intended Parents and the Problem of Perspective, 24 YALE J. L. \& FEM. 210, 217-19 (2012).

28. Id. at 360 .

29. See, e.g., Elizabeth Bartholet, Guiding Principles for Picking Parents, 27 HARV. WOMEN's L.J. 323 (2004); June Carbone \& Naomi Cahn, Which Ties Bind? Redefining the Parent-Child Relationship in an Age of Genetic Certainty, 11 WM. \& MARY BILL RTS. J. 1011, 1022-25 (2003).

30. See Lucy S. McGough \& Lawrence M. Shindell, Coming of Age: The Best Interests of the Child Standard in Parent-Third Party Custody Disputes, 27 EMORY L.J. 209, 209 (1978).

31. See Marvin R. Ventrell, Essay, Rights \& Duties: An Overview of the Attorney-Child Client Relationship, 26 LOY. U. CHI. L.J. 259, 261 (1995).

32. See Mary Becker, Maternal Feelings: Myth, Taboo, and Child Custody, 1 S. CAL. REV. L. \& WOMEN'S STUD. 133, 167-68 (1992). 
self-sufficiency. ${ }^{33}$ Barbara Bennett Woodhouse traced this view through Supreme Court privacy doctrine in her seminal article Who Owns the Child ${ }^{34}$ In her reading, early cases dealing with the right to privacy as based in the family were animated by, among other things, "a conservative attachment to the patriarchal family, to a class-stratified society, and to a parent's private property rights in his children and their labor." ${ }^{35}$

Obviously, such analogies between a parent's rights over his or her children and an adult's control over property have declined, recognizing competing claims to children as a public good and, more importantly, viewing children as individual rights holders. ${ }^{36}$ Modern comparisons are much more attenuated, such as Kevin Maillard's proposal of a stewardship model of parentage, using "the complexities of nontitled claims to property" to provide guidance for "the conflict of parental rights and children's best interests." ${ }^{37}$ Katharine Baker proposed that the relationship between mother and child should be understood as modeled on property rights in order to give mothers greater power. ${ }^{38}$ Other updated parallels include children as intellectual property ${ }^{39}$ and conceptions of property specific to family law, such as community property. ${ }^{40}$ Some vestiges remain, however, particularly in comparing parents' rights to a property owner's right to exclude, as discussed above. ${ }^{41}$

The right to treat one's children as property, however, presupposes an important determination: who the parents are. An analogy to property illuminates not only a parent's rights over his or her children, but also why an adult is identified as the child's parent. Inter-

33. See, e.g., MARY ANN MASON, FROM FATHER'S PROPERTY TO CHILDREN'S RIGHTS: THE HISTORY OF CHILd CUSTODY IN THE UNITED STATES (1994).

34. Barbara Bennett Woodhouse, "Who Owns the Child?": Meyer and Pierce and the Child as Property, 33 WM. \& MARY L. REV. 995 (1992).

35. Id. at 997.

36. Id. at 1068 .

37. Kevin Noble Maillard, Rethinking Children as Property: The Transitive Family, 32 CARDOZO L. REV. 225, 229 (2010).

38. Katharine K. Baker, Property Rules Meet Feminist Needs: Respecting Autonomy by Valuing Connection, 59 OHIO ST. L.J. 1523, 1528 (1998).

39. See, e.g., Merry Jean Chan, Note, The Authorial Parent: An Intellectual Property Model of Parental Rights, 78 N.Y.U. L. REV. 1186 (2003).

40. See, e.g., Jeffrey A. Myers, Are Children Community Property in California?, 16 J. CONTEMP. LEGAL ISSUES 65 (2007).

41. Carter Dillard, Future Children as Property, 17 DUKE J. GENDER L. \& POL'Y 47, 67 (2010) (citing Henry E. Smith, Mind the Gap: The Indirect Relation Between Ends and Means in American Property Law, 94 CoRnell. L. REv. 959, 988 (2009)); see also Felix S. Cohen, Dialogue on Private Property, 9 RuTGers L. REv. 357, 370-71 (1954) ("[L]et us put this down as one more point of agreement in our analysis of the meaning of private property. Private property may or may not involve a right to use something oneself. It may or may not involve a right to sell, but whatever else it involves, it must at least involve a right to exclude others from doing something."). 
estingly, the property analogy not only holds up in examining acquisition of parental rights, but it helps to illuminate one of the major shifts in parentage law in recent decades: the increasing strength of functional theories of parenthood. Finally, the property analogy highlights a growing emphasis on greater claims to the child created through gestational labor.

\section{A. Parental Status as Bodily Unity}

Historically, parenthood was the sole product of biology, or at least the legal fiction of biology. The plainest explanation of this view is that genetic material contributed to a child creates a property claim to that child. Intuitively, it seems obvious that the first logical parents should be the biological parents; in a world before complications such as in vitro fertilization ("IVF"), sperm donation, or even blended families were recognized in law, surely the clearest answer to a question of parentage would be the woman who gave birth to the child and that woman's husband. This "easiest-to-identify" answer would seem to privilege the gestational mother, and yet, in actuality, parentage was explained by analogizing the child as biological property of the father ${ }^{42}$ For hundreds of years, children were seen as an extension of their father's body. As Woodhouse explained,

The notion of the child as property is at least as ancient as the Greek and Judeo Christian traditions identifying man as the procreative force. Consider scripture: God created Eve from Adam's rib, blessed Abraham's seed, and required male circumcision as a primary symbol of the covenant. The patriarchs, and not the matriarchs, begat sons who themselves begat sons. . . . Aristotle believed the child was a parent's possession because it came physically from the parent, like a tooth or a lock of hair. In Aristotle's cosmology, it was the male seed, more divine than the base matter contributed by the female, that gave the child its life. . . . In order to increase their dynastic wealth, men appropriated "as property, the product of the reproductive capacity of subordinate womenchildren, to be worked, traded, married off, or sold as slaves, as the case might be." 43

Children-as "flesh of the parent's flesh" ${ }^{44}$-were seen as a literal extension of their father. His status as parent was thus a fact of nature, justified by the unity of their bodies.

Although family structures were based in part upon the voluntary marital relationship, and actual biological relationships between fa-

42. Woodhouse, supra note 34, at 1043.

43. Id. (footnotes omitted) (quoting Gerda LERner, The CREation of Patriarchy 215 (1986)).

44. Id. at 1044 . 
thers and children could not be determined with certainty, the family was seen as "resulting from and reflecting what were understood as objective facts of nature." 45 These objective facts of nature were what set the home aside from the larger world: family and hearth as a single entity within society. ${ }^{46}$

The genetic explanation, however, was demonstrably incomplete as medical knowledge advanced. One view of human reproduction was that a homunculus, or a tiny but completely formed person, existed in gametes. ${ }^{47}$ Once pregnancy began, the homunculus was developing into the fully-formed baby. ${ }^{48}$ The only medical question, therefore, was in which gamete the homunculus existed, egg or sperm. ${ }^{49}$

As medicine advanced to acknowledge that both biological parents contributed genetic material to the child, however, the law did not follow suit. The equal contributions of both parents did not create equal legal rights in the mother and father. The reason was simple: the father, as long as he was married to the mother, already owned any contribution that she made. ${ }^{50}$ Under the doctrine of coverture, adopted from the English common law, "the husband and wife are one person in law: that is, the very being or legal existence of the woman is suspended during the marriage, or at least is incorporated and consolidated into that of the husband." ${ }^{51}$ Any and all parental rights, therefore, were held solely by the father..$^{52}$

\section{B. The Growth of Labor-Based Theories}

In recent years, however, reliance on bodily unity has been supplanted by growing recognition of parentage as generated by the performance of caretaking work for a child. This parentage right is no longer a product of biology or a natural inheritance, but the product of labor. Parentage, thus, is understood as the product of a Lockean labor interest.

A very simplified summary of John Locke's theory of property is that ownership of property is created and is justified by the labor

45. Janet L. Dolgin, Biological Evaluations: Blood, Genes, and Family, 41 AKRON L. REv. 347, 352 (2008).

46. See id. at 354 .

47. See Kara W. Swanson, Adultery by Doctor: Artificial Insemination, 1890-1945, 87 CHI.-KENT L. REV. 591, 597 \& n. 31 (2012).

48. See id. at 597 .

49. See id. at $597.98 \&$ n.31.

50. See Ann Laquer Estin, Family Law, Pluralism, and Human Rights, 25 EMORY INT'L L. REV. 811, 817 (2011).

51. 1 William BLACKSTONE, COMMENTARIES ON THE LAWS OF ENGLAND 442 (photo. reprint 1978) (London, W. Strahan; T. Cadell; \& Oxford, D. Prince, 9th ed. 1783) (1765) (footnote omitted).

52. Estin, supra note 50, at 817. 
that the owner invested into the property. ${ }^{53}$ Notably, this theory is cleanest as Locke first advanced it, when the property in question was first a natural resource unclaimed by any other individual person, and by virtue of investing labor, the owner claimed it for his own private property-a comparison that does not seem to track particularly well onto children and parents. ${ }^{54}$ The analogy is nonetheless useful as a tool to summarize several aspects of how legal and societal understandings of the family have changed.

First, as discussed above, in some ways children can be regarded as a public good-indeed, as Barbara Bennett Woodhouse pointed out, one of the arguments that chipped away at a father's absolute rights over his children was to recognize children as a public good. ${ }^{55}$ The Supreme Court has acknowledged some forms of public interest in children, acknowledging that a Native American "tribe has an in. terest in the child which is distinct from but on a parity with the in. terest of the parents." ${ }^{56}$ Although there is not a literal natural supply of unclaimed children, in some senses children could be regarded as an undeveloped resource. Viewing childrearing as investing labor and money into a resource, and thus generating a claim to that resource, puts a more precise explanation and name to existing justifications of parents' rights. ${ }^{57}$

Second, the great strength of using Locke's theory in the context of acquiring parental status is in recognizing the value of the labor in. vested into property, as it is recognition of parental labor (as opposed to the natural right of bodily unity) that underlies the evolution of modern family law. As Anupam Chander explains,

For Locke, the major part of the value of a thing arises from human endeavor, not from the thing's natural state of being. Deriv-

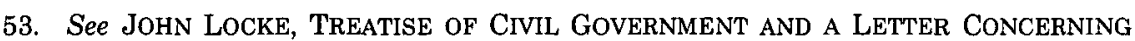
Toleration 19 (Charles L. Sherman ed., D. Appleton-Century Co. 1937) (1689) ("Whatsoever, then, he removes out of the state that nature hath provided and left it in, he hath mixed his labour with, and joined to it something that is his own, and thereby makes it his property." (emphasis added)).

54. Locke also acknowledged in his Second Treatise that "paternal power" appears to place all parental power in the hands of the father, where the mother should have equal power over the child. JOHN LOCKE, Two TREATISES OF GOVERNMENT 146 (Thomas I. Cook ed., Hafner Pub. Co. 6th prtg. 1965) (1690).

55. See Woodhouse, supra note 34, at 1068.

56. Mississippi Band of Choctaw Indians v. Holyfield, 490 U.S. 30, 52 (1989) (quoting In re Adoption of Halloway, 732 P.2d 962, 969 (Utah 1986). Notably, the Court also quoted language from the Utah Supreme Court's decision noting that the relationship between tribe and children raised on a tribal reservation "finds no parallel" in other cultures. Id.

57. See, e.g., Cynthia A. McNeely, Comment, Lagging Behind the Times: Parenthood, Custody, and Gender Bias in the Family Court, 25 FLA. ST. U. L. REV. 891,897 (1998) ("Courts, during a time when the culture was agrarian and children worked in the fields, upheld this action by finding that the father's financial support of his children entitled him to the benefits of their labor."). 
ing property rights from labor becomes more intuitively appealing if one believes that it is the labor itself that gave the worked-upon object its value. It is this belief that leads Locke's theory to be characterized as one of moral desert: the law grants a person a property right in a thing because that person deserves it as a reward for the virtue of having created the major part of its value. ${ }^{58}$

Focusing on the value of a parent's investment thus strengthens the analogy considerably. The recognition of parental labor-often in practice maternal labor-has driven some of the most extensive modern reforms to parentage law.

The shift first appeared in the context of custody disputes. Custody disputes generally weigh competing claims brought by two legal parents, typically the mother and father. It is not, therefore, an identification of parents. Because custody disputes in effect determine many of the tangible rights of parenthood, however, they help to illuminate who a child's "real," or more active, parent is seen to be and why. ${ }^{59}$

Historically, under the property-as-bodily-unity analogy discussed above, fathers not only had near complete power over children as a right in intact families, ${ }^{60}$ but they also had the right to have their children with them. ${ }^{61}$ A Massachusetts case from 1834 stated quite plainly that "in general, ... the father is by law clearly entitled to the custody of his child." 62

The first shift away from a strict rule of father's dominion in custody disputes was the tender years doctrine, meaning that young children of "tender years" should live with their mother, ${ }^{63}$ but an older child should be given into the custody of the parent of the child's sex. ${ }^{64}$ Maine was one of the first jurisdictions to move toward the ten-

58. Anupam Chander, The New, New Property, 81 TEX. L. REV. 715, 742 (2003).

59. Many divorces involving children never generated a custody dispute because one parent, generally the father, did not seek primary custody. To the extent that one might draw an explicitly gendered conclusion from the cases that did require judicial intervention, therefore, reported custody cases present a nontypical subset of custody determinations. For purposes of my analysis, however, this does not present a problem: the vast majority of both custody and parentage disputes are uncontested. The rules used to settle both types of disputes are exceptional in use, but important (as I will discuss further below) for the purposes of setting defaults and serving expressive or channeling functions.

60. Lynne Marie Kohm, Tracing the Foundations of the Best Interests of the Child Standard in American Jurisprudence, 10 J.L. \& FAM. STUD. 337, 345 (2008).

61. Martha L. Fineman \& Anne Opie, The Uses of Social Science Data in Legal Poli. cymaking: Custody Determinations at Divorce, 1987 WIS. L. REV. 107, 111.

62. Commonwealth v. Briggs, 33 Mass. (16 Pick.) 203, 205 (1834).

63. Fineman \& Opie, supra note 61, at 112; Jamil S. Zainaldin, The Emergence of a Modern American Family Law: Child Custody, Adoption, and the Courts, 1796-1851, 73 NW. U. L. REV 1038, 1072-73 (1979).

64. Fineman \& Opie, supra note 61, at 112; see also Zainaldin, supra note 63 , at 1073 ("[W] (footnote omitted)). 
der years doctrine, and the Maine Supreme Court's analysis concisely demonstrates the analytical shift. In State $v$. Smith, Jonathan Hall had drawn up an agreement with his wife stating that "if, in consequence of any ill treatment by him, his wife should be rendered unhappy and unwilling to cohabit with him," she would receive custody of their three children.$^{65} \mathrm{He}$ later challenged the agreement, arguing that as father he had a "paramount right" to the children. ${ }^{66}$ The court disagreed-but its analysis initially seemed to treat the dispute solely under a contractual disposition of the father's natural property, noting that since fathers had the right to assign the services of their children by sending them out as apprentices to learn a trade, Hall should be bound by his contract. ${ }^{67}$ The court then turned, however, to the ages of the children, noting that it could not "forget that the eldest of these children is a daughter, requiring peculiarly the superintendence of a mother." ${ }^{\prime 8}$ This focus on the gendered needs of children old enough to require modeling of their socially determined sex roles exemplifies the tender years doctrine; as Jamil Zainaldin described it, "the judiciary's interpretation of the law of nature." 69

The tender years doctrine rose to prominence in Britain the 1840s, and by the early twentieth century, most American courts had adopted some form of the doctrine, which held sway in most states' custody laws until the late $1960 \mathrm{~s} .{ }^{70}$ The doctrine, although it granted greater preeminence to the nurturing, caretaking work performed by women, still rested in part on biology: mothers were judged the appropriate custodians of younger children due in large part to assumptions that mothers were better and more nurturing caretakers, but the assumptions in turn were justified by stereotypes about sex roles. ${ }^{71}$

In the middle of the twentieth century, the focus turned from the sex roles of the parents to the psychological well-being of the child as

65. State v. Smith, 6 Me. 462, 463 (1830) (quotation marks omitted).

66. Id. at 464 .

67. Id. at 465 .

68. Id. at 468 .

69. Zainaldin, supra note 63 , at 1070 .

70. See Julie E. Artis, Judging the Best Interests of the Child: Judges' Accounts of the Tender Years Doctrine, 38 LAW \& Soc'Y REv. 769, 774 (2004); see also Gary Crippen, Stumbling Beyond Best Interests of the Child: Reexamining Child Custody Standard-Setting in the Wake of Minnesota's Four Year Experiment with the Primary Caretaker Preference, 75 MinN. L. REv. 427, 433-34 (1990); Sanford N. Katz, "That They May Thrive" Goal of Child Custody: Reflections on the Apparent Erosion of the Tender Years Presumption and the Emergence of the Primary Caretaker Presumption, 8 J. CONTEMP. HEALTH L. \& POL'Y 123, 126-28 (1992); Allan Roth, The Tender Years Presumption in Child Custody Disputes, $15 \mathrm{~J}$. FAM. L. 423, 429 (1976). As will be discussed further below, although the tender years doctrine is no longer formally used in custody determinations, some studies indicate that in practice, assumptions about the relative nurturing skills and instincts of men and women largely replicate the doctrine's effect. See, e.g., Artis, supra, at 783-85.

71. See Artis, supra note 70, at 784-85. 
formed in large part by caretaking labor. Attachment theory, as advocated by child psychologists, explained that a child's interactions with the person responsible for the bulk of the everyday caregiving work created a strong emotional and psychological bond. ${ }^{72}$ This attachment was "the essential cornerstone for a child's healthy emotional development," 73 and a child separated from the person to whom she had formed such an attachment would suffer severe and permanent psychological trauma. ${ }^{74}$

Attachment theory laid the groundwork for the primary caretaker standard or factor in custody determinations. The primary caretaker standard directed a court to assess the caretaking labor in order to identify one parent as the primary caretaker of the child. ${ }^{75} \mathrm{~A}$ West Virginia case explaining the standard summarized specific daily tasks to be considered:

(1) [P]reparing and planning of meals; (2) bathing, grooming and dressing; (3) purchasing, cleaning, and care of clothes; (4) medical care, including nursing and trips to physicians; (5) arranging for social interaction among peers after school . . . ; (6) arranging alternative care, i. e. babysitting . . . ; (7) putting child to bed at night, attending to child in the middle of the night, waking child in the morning; (8) disciplining, i. e. teaching general manners and toilet training; (9) educating, i. e. religious, cultural, social, etc.; and, (10) teaching elementary skills, i. e. reading, writing and arithmetic. ${ }^{76}$

Although the primary caretaker standard was justified by concepts from attachment theory protecting a close parent/child bond, the caretaking parent had to prove that he or she created the bond through his or her daily labor. ${ }^{77}$ Use of the primary caretaker standard to identify a single primary caretaker and award custody to that parent was only temporarily applied in West Virginia and Minnesota. ${ }^{78}$ Identification of the primary caretaker, however, remains as one factor-albeit not a dispositive one-to be considered in custody determinations in many states. ${ }^{79}$

72. See David L. Chambers, Rethinking the Substantive Rules for Custody Disputes in Divorce, 83 MICH. L. REV. 477, 528-30 (1984).

73. Id. at 529 .

74. Peggy Cooper Davis, The Good Mother: A New Look at Psychological Parent Theory, 22 N.Y.U. REV. L. \& SOC. CHANGE 347, 347 (1996).

75. See Crippen, supra note 70 , at $434-35$.

76. Garska v. McCoy, 278 S.E.2d 357, 363 (W. Va. 1981).

77. See Crippen, supra note 70, at $439-42$.

78. See Pamela Laufer-Ukeles, Selective Recognition of Gender Difference in the Law: Revaluing the Caretaker Role, 31 HARV. J.L. \& GENDER 1, $48-49$ (2008); see also Becker, supra note 32, at 171 \& n.148; Crippen, supra note 70, at 428-29.

79. See Alexandra Selfridge, Equal Protection and Gender Preference in Divorce Contests over Custody, 16 J. CONTEMP. LEGAL IsSUES 165, 172 (2007). 
The move toward recognition of parental labor has had greater effect in the context of parentage determinations. The primary caretaker standard and attachment theory arose as part of custody determinations, identifying which parent would be a better physical custodian for a child. ${ }^{80}$ Functional theories of parentage, by contrast, use the same assessment of caretaking labor to define parenthood itself, and consequently use labor as a test to identify legal parents. For example, in a 2000 case from New Jersey, a lesbian couple started a family through the artificial insemination of one of the women. ${ }^{81}$ When the resulting twins were two years old, the women broke up, and the woman with no genetic link to the children asked for visitation. ${ }^{82}$ The New Jersey Supreme Court adopted a test for "psychological parenthood," requiring that "the legal parent must consent to and foster the relationship between the third party and the child; the third party must have lived with the child; the third party must perform parental functions for the child to a significant degree; and most important, a parent-child bond must be forged." 83 The court noted that the nonbiological mother in the case had "labored alongside" the biological mother in performing caretaking work and thereby created an emotional bond with the children. ${ }^{84}$ This labor itself created her status as psychological parent..$^{85}$

Importantly, functional theories do not necessarily create status as legal parent: as in the New Jersey case, functional theories sometimes merely give the adult some legal standing to request visitation or custody that is nonetheless subordinate to status as legal parent. ${ }^{86}$ Such theories have been gaining in strength in recent decades, however, and have increasing applicability in multiple contexts. ${ }^{87}$ Nancy Polikoff has written extensively advocating for functional theories of parentage, particularly in the context of same-sex couple parents, proposing "expanding the definition of parenthood to include anyone who maintains a functional parental relationship with a child when a legally recognized parent created that relationship with the intent

80. See, e.g., Garska, 278 S.E.2d at 361 (" [W]e are convinced that the best interests of the children are best served in awarding them to the primary caretaker parent, regardless of sex.").

81. V.C. v. M.J.B., 748 A.2d 539, 542 (N.J. 2000).

82. Id. at 544 .

83. Id. at $551-52$.

84. Id. at 550 .

85. Id. at 555 .

86. See Purvis, supra note 27, at 226-27.

87. See, e.g., Katharine T. Bartlett, Rethinking Parenthood as an Exclusive Status: The Need for Legal Alternatives When the Premise of the Nuclear Family Has Failed, 70 VA. L. REV. 879 (1984); Melanie B. Jacobs, Micah Has One Mommy and One Legal Stranger: Adjudicating Maternity for Nonbiological Lesbian Coparents, 50 BUFF. L. REV. 341 (2002). 
that the relationship be parental in nature." 88 Functional theories have had considerable influence in the context of paternity disestablishment, meaning a man discovers that a child he believed was his biological child is not. Under theories of "equitable parenthood," such a father is entitled to protect his status as legal parent notwithstanding the lack of a genetic link, by virtue of the relationship he created with the child. ${ }^{89}$ Should the father be the one seeking to terminate his status as legal parent, states are mixed as to whether he is allowed to do so-several jurisdictions lock in legal fathers even if the labor they put in as father was effectively the product of fraud. ${ }^{90}$ Functional theories have also been proposed as a way to unbundle some of the rights and duties attendant with status as legal parent, such as inheritance rights. ${ }^{91}$

One of the modern strands of functional theories turns to the bodily labor of women. Historical recognition of pregnant women as mothers was expressed as mater est quam gestation demonstrat, or "by gestation the mother is demonstrated." 92 Until recently, this was also a reiteration of the reliance on genetic link as generating parenthood. Today, however, with the advent of gestational surroga$c y$, in which an embryo is implanted into the uterus of a surrogate who carries the pregnancy to term, the assumption no longer holds true.

Even outside the context of surrogacy, multiple scholars explain parental rights as justified by the labor of the pregnant woman. Katharine Baker, for example, notes that a mother's de facto control over her child "suggests that the gestational mother gains parental status through her gestational investment, not through her genetic contribution." ${ }^{93}$ Jennifer Hendricks applauds the Supreme Court for refusing to "ignore[] any uniquely female experience and define[] parenthood as genetic contribution, giving biological fathers equal

88. Nancy D. Polikoff, This Child Does Have Two Mothers: Redefining Parenthood to Meet the Needs of Children in Lesbian-Mother and Other Nontraditional Families, 78 GEo. L.J. 459, 464 (1990).

89. See Atkinson v. Atkinson, 408 N.W.2d 516 (Mich. Ct. App. 1987).

90. See Melanie B. Jacobs, My Two Dads: Disaggregating Biological and Social Paternity, 38 ARIZ. ST. L.J. 809, 837-43 (2006) [hereinafter Jacobs, My Two Dads]; Melanie B. Jacobs, When Daddy Doesn't Want to Be Daddy Anymore: An Argument Against Paternity Fraud Claims, 16 YALE J.L. \& FEMINISM 193 (2004) [hereinafter Jacobs, An Argument Against Paternity Fraud Claims].

91. E. Gary Spitko, Open Adoption, Inheritance, and the "Uncleing" Principle, 48 SANTA CLARA L. REV. 765, 767 (2008) ("[T] he article proposes reforming intestacy statutes to allow an adopted child and her birth parent who have maintained a 'qualifying functional relationship' following an open adoption to inherit from and through each other as would an aunt or uncle and a niece or nephew.").

92. Hill, supra note 26 , at 370 .

93. Katharine K. Baker, Bargaining or Biology? The History and Future of Paternity Law and Parental Status, 14 CORNELL J.L. \& PUB. POL'Y 1, 47 (2004). 
rights with biological mothers." ${ }^{94}$ In her reading, the Supreme Court was correct to refuse to grant status as legal parent to an unwed biological father who did not have a relationship with his child because to do so would "reinforce the notion that biological fathers 'own' their offspring regardless of whether they have functioned as parents." ${ }^{95} \mathrm{E}$. Gary Spitko explains that a "biological mother's constitutional parental rights arise ... from her role nourishing the child in her womb and enduring the pain and danger of childbirth," 96 and proposes collapsing biological relationships into functional theories by recognizing the parentage of biological fathers only if the biological mother consents to the relationship. ${ }^{97}$ Spitko rests his argument explicitly on the value of parental labor:

The biological father is situated dramatically differently from the biological mother with respect to the labor necessary for the child's birth. The biological father's role in conceiving the child is constitutionally insignificant as labor. He has no role, of course, in physically carrying and giving birth to the child. He does not qualify, therefore, for automatic constitutional protection under the labor-with-consent theory of constitutional parental rights. ${ }^{98}$

Parentage as labor has thus gained ground over parentage as bodily unity, but this is not to say that one theory has replaced the other. An interesting consequence of the growing strength of parentage as labor is in shifting justifications for existing doctrine. One example, to which the next section turns, is the marital presumption.

\section{Case Study: The Marital Presumption}

The marital presumption creates a rule of legal parentage that when a married woman gives birth, her husband is presumed to be the legal father of the child. The presumption was historically a rigid rule, but it has weakened in recent decades..$^{99}$ Although almost half of U.S. states still have some form of the presumption in their laws, it is generally employed as a relatively weak rebuttable presumption, rather than an ironclad rule. ${ }^{100}$

94. Jennifer S. Hendricks, Essentially a Mother, 13 WM. \& MARY J. WOMEN \& L. 429, 451 (2007).

95. See id. at 452-53 (criticizing the application by lower courts of Supreme Court cases addressing the rights of unwed biological fathers).

96. E. Gary Spitko, The Constitutional Function of Biological Paternity: Evidence of the Biological Mother's Consent to the Biological Father's Co-Parenting of Her Child, 48 ARIZ. L. REV. 97, 99 (2006).

97. Id. at 100-05.

98. Id. at 109 (footnotes omitted).

99. Susan Frelich Appleton, Presuming Women: Revisiting the Presumption of Legitimacy in the Same-Sex Couples Era, 86 B.U. L. REv. 227, 228 (2006).

100. Id. at 234-36. 
The justifications offered for the marital presumption have undergone a progression from a focus on parentage justified by biology to parentage justified by labor. Historically, the marital presumption codified an assumed biological link. ${ }^{101}$ Long before paternity tests were available, in other words, the marital presumption assumed that married women did not bear children fathered by men other than their husbands. ${ }^{102}$ At times, this assumption approached the level of willful blindness: in England, the marital presumption could only be overcome if the husband was "beyond the four seas" during the time in which a child was conceived, proving by physical impossibility that he was not the child's biological father. ${ }^{103}$ Evidentiary bars went even further, barring the spouses themselves from testifying as to the husband's presence in the home during the time of probable conception. ${ }^{104}$

The marital presumption began, therefore, as a legal fiction of biological link-a legal fiction that was no doubt in most cases actually true. ${ }^{105}$ But to the extent that the presumption legally codified biological bonds that did not actually exist-perhaps that the fathers occasionally knew did not exist-what purpose did the presumption serve? In an era when illegitimate children suffered explicit discrimination and a woman's worth was set by her sexual morality, ${ }^{106}$ concerns for the individual people involved cannot be dismissed. But another purpose served was to provide legal protection for family relationships that already existed: if the husband was willing to continue living with his wife and providing for his family, the familial relationships should be legally protected. ${ }^{107}$

Modern discussions of the marital presumption have elucidated this point. A California appeals court, discussing California's conclusive marital presumption of parentage, noted that initially, the law was justified "on the ground that no competent evidence could be adduced to indicate who among those who had had intercourse with the

101. See David D. Meyer, Parenthood in a Time of Transition: Tensions Between Legal, Biological, and Social Conceptions of Parenthood, 54 AM. J. COMP. L. 125, 130 (2006).

102. See Janet L. Dolgin, Choice, Tradition, and the New Genetics: The Fragmentation of the Ideology of Family, 32 CONN. L. REv. 523, 527 (2000) (describing the presumption as "elid[ing] the biological facts in an era in which they were unknowable").

103. Meyer, supra note 101, at 127.

104. Appleton, supra note 100 , at 232-33.

105. See Leslie Joan Harris, Reconsidering the Criteria for Legal Fatherhood, 1996 UTAH L. REV. 461, 463 ("At common law, marriage was the defining criterion for a man to be recognized as a child's legal parent. However, in practice the law also protected functional and biological family relationships because adults rarely lived together openly as mates without being married, and unwed parenthood was strongly socially disapproved, at least within the social groups whose mores were dominant.")

106. See Johanna Bond, Honor as Property, 23 CoLUM. J. GENDER \& L. 202, 205, 211 (2012).

107. See Harris, supra note 105 , at $463-64$. 
wife during the period of possible conception was the biological father of the child born to her." ${ }^{108}$ The California state legislature later justified the "conclusive presumption fiction" on three grounds: "(1) preservation of the integrity of the family; (2) protection of the innocent child from the social stigma of illegitimacy; and (3) a desire to have an individual rather than the state assume the financial burden of supporting the child." ${ }^{109}$ The court then noted that the legislature amended the law to admit some blood tests disproving paternity, but with strict limits that only the husband could introduce such tests and only within the first two years of the child's life. ${ }^{110}$ The explanation, the court speculated, was "probably found" in an article in the Stanford Law Review, and quoted what it believed was the key reasoning:

"[ []$n$ the case of an older child the familial relationship between the child and the man purporting to be the child's father is considerably more palpable than the biological relationship of actual paternity. A man who has lived with a child, treating it as his son or daughter, has developed a relationship with the child that should not be lightly dissolved and upon which liability for continued responsibility to the child might be predicated. This social relationship is much more important, to the child at least, than a biological relationship of actual paternity." 111

The work put in by the husband, the parenting labor creating a relationship, thus justified the legal protection.

This is not to say that labor-based theories of the acquisition of parental status have entirely replaced bodily unity as a theory of how parental status is created. The growing dominance of a labor-based theory of the acquisition of parenthood, however, helps to explain a web of parentage rules that seem at first blush to be in conflict: the laws governing fatherhood.

\section{FATHERHOOD AS LABOR}

The law creates a curious contrast in defining who is a father. In the context of child support, a biological connection is all that is needed to trigger, if exercised, an obligation to pay child support for the duration of the child's minority. ${ }^{112}$ In other contexts, however, a

108. Stephen B. v. Sharyne Sue B. (In re Marriage of Stephen \& Sharyne B.), 177 Cal. Rptr. 429, 431 (Cal. Ct. App. 1981).

109. Id. at 432 .

110. Id.

111. Id. at 432-33 (quoting William P. Hoffman, Jr., Recent Developments, California's Tangled Web: Blood Tests and the Conclusive Presumption of Legitimacy, 20 STAN. L. REV. $754,761(1968))$.

112. See, e.g., Susan Frelich Appleton, Mlegitimacy and Sex, Old and New, 20 AM. U. J. GENDER SOC. POL'Y \& L. 347, 366 (2012). 
biological father who is not married to the biological mother is not viewed as the legal father of the child, even where he strenuously seeks that status. Unwed biological fathers are, at least in some contexts, locked both in and out of parenthood by the law.

The move from bodily unity to labor helps to explain this. The male property "interest" in his genetic material is locked in once gestational labor begins. This interest is necessary for parental status, but not yet sufficient-in order for him to claim his status as legal parent, he has to contribute parental labor.

\section{A. Where Fathers Are Locked In}

In the words of June Carbone and Naomi Cahn, while "[s]hotgun marriage may be dead; shotgun parenthood is not." ${ }^{113}$ Child support is one of the largest obligations-in duration, amount, and strengthimposed by the law. It foists the fiscal duties of parenthood upon people, mostly men, regardless of whether they desire to be a parent.

Child support is premised in almost all circumstances on biological link. ${ }^{114}$ The obligation is so strong that even in extreme examples where crimes were committed in the conception of the child, the victim is nonetheless responsible for fiscal support of his biological child.

Multiple men have attempted to argue that they were defrauded by women who lied about the possibility of their becoming pregnant. In one Michigan case, a biological father argued that he had expressly told the biological mother that he did not want to be a father and was assured that not only was the woman using contraceptives, but also that she was infertile. ${ }^{115}$ The father brought a suit under 42 U.S.C. § 1983, arguing that the Michigan Paternity Act violated the Federal Constitution's Equal Protection Clause "by denying men, but not women, 'the right to initiate [sic] consensual sexual activity while choosing not to be a parent." "116 This argument was roundly rejected. ${ }^{117}$ Another unwilling father, Peter Wallis, faced similar facts: he claimed that he had discussed with his sexual partner his desire not to father a child and was assured that she was taking birth control pills. ${ }^{118}$ She stopped taking birth control pills but did not inform Wallis. ${ }^{119}$ Wallis did not seek to terminate his child support obligation but

113. Carbone \& Cahn, supra note 29 , at 1025.

114. Susan Frelich Appleton draws upon the explanations of child support to argue that child support is one method that the state uses to control (and tax) heterosexual intercourse. See Appleton, supra note 112, at 366-67.

115. Dubay v. Wells, 506 F.3d 422, 426 (6th Cir. 2007).

116. Id. at 427-30 (quoting Appellant's Final Brief on Appeal at 11, Dubay v. Wells, 506 F.3d 422 (6th Cir. 2007) (No. 06-2107), 2007 WL 2735358, at *11).

117. Id. at 430 .

118. Wallis v. Smith, 22 P.3d 682, 683 (N.M. Ct. App. 2001).

119. Id. 
sought compensatory and punitive damages from the mother on the basis of fraud, breach of contract, tort (measuring damages by the cost of raising a child), and most creatively, conversion-_purloined sperm," as one commentator described it. ${ }^{120}$ Again, the father's claims were rejected, citing the state legislature's "public policy that governs the economic consequences of sexual relationships that produce children, . . . reflected in [the state's] child support laws." ${ }^{121}$ Finding that it was "self-evident" that Wallis was attempting to avoid paying child support, the court explained that public policy established strict liability for the "financial responsibility of [a] child." ${ }^{22}$

Even more extreme allegations regarding fraud as part of sexual activity have been made in litigation. More than one reported case rested on claims that the couple did not actually have sexual intercourse. ${ }^{123}$ The man in each case asserted that he had only engaged in oral sex with a woman who had then artificially inseminated herself. ${ }^{124}$ Admittedly, these claims may be too bizarre to be believedand one claim was indeed rejected on the merits, despite testimony from a witness who had walked in on the alleged self-insemination in a bathroom. ${ }^{125}$ In a 2005 Illinois case, however, the father's claims of fraudulent misrepresentation and conversion were dismissed as failing to state a cause of action. ${ }^{126}$ In other words, the court, for the purposes of evaluating the motion to dismiss, assumed his factual allegations to be true and concluded that even if his account was accurate he was nonetheless still liable for child support. ${ }^{127}$ (The court did allow a claim of intentional infliction of emotional distress to move forward. ${ }^{128}$ ) The dismissal of these claims is typical. Although a number

120. Donald C. Hubin, Daddy Dilemmas: Untangling the Puzzles of Paternity, 13 CoR. NELL J.L. \& PUB. POL'Y 29, 52 (2003) (citing Wallis, 22 P.3d at 683).

121. Wallis, 22 P.3d at 684 .

122. Id. at 683-84.

123. See, e.g., Phillips v. Irons, No. 1-03-2992, 2005 WL 4694579, at *1 (Ill. App. Ct. Feb. 22, 2005); State v. Frisard, 694 So. 2d 1032, 1035 (La. Ct. App. 1997).

124. See, e.g., Phillips, 2005 WL 4694579, at *1; Frisard, 694 So. $2 d$ at 1035.

125. Frisard, 694 So. 2 d at 1035.

126. Phillips, 2005 WL 4694579 , at *5-6. Entertainingly, although the court noted that other jurisdictions had recognized a "property right" in body materials, it rejected the man's conversion claim with the reasoning that he could not "show he had the 'right to immediate, absolute, and unconditional possession' of his sperm. Plaintiff presumably in. tended, and he does not claim otherwise, that defendant discard his semen, not return it to him." Id. at *6.

127. Although Phillips's arguments followed the model of Peter Wallis and did not explicitly challenge his child support obligation, it seems obvious that at least some of the damages he hoped to secure would have compensated him for his $\$ 800$ monthly child support payment. See Associated Press, Sperm: The 'Gift' That Keeps on Giving, NBCNEWS.COM (Feb. 24, 2005, 2:39 PM), http://www.nbenews.com/id/7024930/ns/healthsexual_health/t/sperm-gift-keeps-giving/\#.U1L6u1VdWSo.

128. Phillips, 2005 WL 4694579 , at $* 5$. 
of cases alleging contraceptive fraud have been attempted, ${ }^{129}$ even where elements of misrepresentation are arguably shown, courts conclude that public policy blocks the claims. ${ }^{130}$ (Arguments that the women have refused to mitigate the damages of child support by terminating their pregnancies have been similarly unsuccessful. ${ }^{131}$ ) Interestingly, there is some evidence that the dismissal of unwilling fathers' suits is gendered, as at least some claims brought by women seeking reimbursement for the costs of pregnancy or of an abortion have been successful. ${ }^{132}$

In any case, claims of fraud in an intimate context raise evidentiary and privacy concerns that might justify refusing to adjudicate them. Such concerns are not present, however, in the context of fathers who could not have legally consented to intercourse, and yet child support obligations are frequently imposed on such fathers. Boys who are victims of statutory rape, for example-whose abusers are convicted and in some cases imprisoned for the act-are held liable for child support. ${ }^{133}$ Even allegations of the rape of adults are rejected as excusing a child support obligation. In an Alabama case, a man alleged that the child whose support he was liable for was the product of sexual assault. ${ }^{134} \mathrm{He}$ had attended a party at the mother's house and, according to the testimony of many witnesses, had become intoxicated to the point of passing out. ${ }^{135}$ After that night, the mother

129. Adrienne D. Gross, Note, A Man's Right to Choose: Searching for Remedies in the Face of Unplanned Fatherhood, 55 DRAKE L. REV. 1015, 1020-21 (2007).

130. Id. at 1023 \& n.56 ("The underlying inquiry in this case is whether the injuries claimed are in fact actionable. Public policy persuades us that they are not." (quoting Welzenbach v. Powers, 660 A.2d 1133, 1135 (N.H. 1995))).

131. Id. at 1027 ("As fault in conception is not relevant to the needs and requirements of a child, a father's claim of fraud cannot be used to mitigate the amount of child support. Because most courts do not find there to be actual damages claimed, this argument is of little merit. It is impossible to mitigate damages that do not even exist." (footnotes omitted)).

132. See Sarah E. Rudolph, Inequities in the Current Judicial Analysis of Misrepresen. tation of Fertility Claims, 1989 U. CHI. LEGAL F. 331 (arguing that differential treatment of misrepresentation of contraceptive use claims is rooted in a perception of women as unable to support or protect themselves); $c f$. Jill E. Evans, In Search of Paternal Equity: A Father's Right to Pursue a Claim of Misrepresentation of Fertility, 36 LOY. U. CHI. L.J. 1045, 1047. 48 (2005) (arguing that although refusal of relief in contraceptive fraud cases is appropriate, the justifications for refusal have thus far been inconsistent). See also M.B.W. Sinclair, Seduction and the Myth of the Ideal Woman, 5 LAW \& INEQ. 33, 33 (1987) (tracing the evolution of the tort of seduction as tied to the "myth of the ideal woman"); Jill Elaine Hasday, Intimate Lies (unpublished manuscript) (on file with author).

133. See Ruth Jones, Inequality from Gender-Neutral Laws: Why Must Male Victims of Statutory Rape Pay Child Support for Children Resulting from Their Victimization?, 36 GA. L. REV. 411, 411-12 (2002); see also State ex rel. Hermesmann v. Seyer, 847 P.2d 1273, 1278-79 (Kan. 1993) (collecting cases); Stringer v. Dep't of Human Servs. ex rel. Baker (In re Paternity of K.B.), 104 P.3d 1132, 1134-35 (Okla. Civ. App. 2004) (same).

134. S.F. v. State ex rel. T.M., 695 So. 2d 1186, 1187-88 (Ala. Civ. App. 1996).

135. Id. 
allegedly told another witness that the mother had sexual intercourse with the man while he was passed out, and that doing so had "saved her a trip to the sperm bank." ${ }^{136}$ The court declined to rule on whether this account was correct, instead concluding that "any wrongful conduct on the part of the mother should not alter the father's duty to provide support for the child." ${ }^{137}$ Even if the child was the product of rape committed against the father, in other words, the child support obligation remained.

In short, despite some attempts by scholars to craft a consentbased model for parenthood, men have virtually no negative procreational right, at least in the context of biological children. ${ }^{138}$ Moreover, those exceptions to the rule that do exist illuminate the interaction between biology and labor.

\section{B. Exceptions to the Biological Rule}

Despite the extremely strong imposition of child support based solely on genetic connection, biological fathers in limited circumstances can evade legal parentage. One example is straightforward: sperm donors, so long as the donation took place in a clinical setting, are not legal parents and are not subject to child support obligations. ${ }^{139}$ This is the case not only where the mother secures sperm from an anonymous donor, but also where she and the donor know each other. ${ }^{140}$ Analogy to property theory provides one explanation, that through the clinical context the genetic material has entered into commerce. The mother is not, in other words, claiming the child by virtue of labor that she invested into material that was otherwise in the commons. She owns the genetic material because she paid for it-but that payment, even though it is not paid directly to the donor, severs all other claims.

A second example from the world of assisted reproductive technologies ("ART") is less clear-cut. When in vitro fertilization is used, embryos are created outside of a woman's body (colloquially, "test tube babies"), and some of the embryos are then implanted into the

136. Id. at 1188 (quotation marks omitted).

137. Id. at 1189 .

138. See Michael J. Higdon, Fatherhood by Conscription: Nonconsensual Insemination and the Duty of Child Support, 46 GA. L. REV. 407 (2012) (proposing that a consent-based model of fatherhood as recognized in the context of artificial insemination be adopted in the context of sexual assault); see also Christopher Bruno, Note, A Right to Decide Not to Be a Legal Father: Gonzales v. Carhart and the Acceptance of Emotional Harm as a Constitutionally Protected Interest, 77 GEO. WASH. L. REV. 141, 150 (2008) (arguing that "a declaration of legal paternity may violate the father's right to procreational autonomy").

139. See In re K.M.H., 169 P.3d 1025, 1034-35 (Kan. 2007).

140. Id.; Ferguson v. McKiernan, 940 A.2d 1236, 1238 (Pa. 2007). 
uterus to hopefully be brought to term. ${ }^{141}$ IVF typically creates more embryos than are implanted in a single pregnancy. ${ }^{142}$ The remaining embryos are stored by the fertility clinic so that they will be available for use by the parents should they desire more children. ${ }^{143}$ In the interim, however, co-parents occasionally end their relationship and disagree about whether and how the remaining embryos will be used. ${ }^{144}$

In contrast to the unwilling child support obligors, these biological fathers have been successful in claiming that procreative liberty in. cludes a right to block such embryos from being used. For example, in Davis $v$. Davis, Junior Davis was able to prevent his ex-wife Mary Sue Davis from being granted "custody" of seven stored preembryos. ${ }^{146}$ The Tennessee Supreme Court first determined that the preembryos were an interim category somewhere between "per. sons" 146 and "property," in which both Davises had "an interest in the nature of ownership." 147 In the absence of agreement between the Davises, the court balanced their relative interests and concluded that "[0]rdinarily, the party wishing to avoid procreation should prevail." 148 Similarly, the Massachusetts Supreme Court found that a consent form signed by former spouses giving stored preembryos to the wife was unenforceable because "forced procreation is not an area amenable to judicial enforcement." 149

Again, the property analogy is helpful. In contrast to the traditional child support claims created through sexual intercourse, at the point that preembryos are stored in a fertility clinic's freezer, the mother has not yet contributed any labor to the embryo. Assisted re. productive technology thus provides a greater window of time in which the contributions of both potential parents-genetic materialare equal. Because the mother's gestational labor has not yet begun, she does not have a greater claim to the status of parent and the attendant decisionmaking abilities.

Interestingly, some criticisms of the embryo storage cases support this point. One common argument, which has been acknowledged by

141. June Carbone \& Naomi Cahn, Embryo Fundamentalism, 18 WM. \& MARY BILL RTS. J. 1015, 1015-16 (2010).

142. Id. at 1016.

143. Id.

144. Id. at 1021.

145. Davis v. Davis, 842 S.W.2d 588, 589, 604-05 (Tenn. 1992).

146. To some extent, as June Carbone and Naomi Cahn point out, this sidesteps questions about the "moral status" of embryos and preembryos. See Carbone \& Cahn, supra note 141.

147. Davis, 842 S.W.2d at 597.

148. Id. at 604 .

149. A.Z. v. B.Z., 725 N.E.2d 1051, 1057-58 (Mass. 2000). 
courts faced with the issue, is that women's reproductive possibilities are limited by biology in a way that men's are not. ${ }^{150}$ One limitation is time: the usable eggs from a single woman are limited in number and decrease in numbers and efficacy as she ages. ${ }^{151}$ Stored preembryos are thus specimens taken from a sharply limited resource. Another limitation, however, is the intrusiveness of harvesting eggs from a woman as compared to sperm donation. More than one commentator has argued the point that since preembryos exist, the potential mother has put labor into the prepregnancy that the potential father has not, and thus she is due more decisional rights over the preembryos. ${ }^{152}$

In acknowledging the relative power of genetic mothers and fa. thers, then, it becomes clear that there is an imbalance in the sense that pregnant women, who are contributing bodily labor, have greater decisionmaking power than men who are not yet contributing any labor. After birth, however, the imbalance continues when the mother and father are unmarried. The next section explains how laborbased theories of parentage help to illuminate the legal treatment of unwed biological fathers.

\section{Unwed Biological Fathers and the Supreme Court}

The clearest example of the genesis of fatherhood-an investment of genetic material plus later parental labor-is manifested in a line of Supreme Court cases dealing with the claims of unwed biological fathers to parenthood. As explained above, unwed biological fathers are required to create a substantial relationship with their child before their parental rights and status are constitutionally cognizable. The Court's opinions place emphasis on the importance of an unwed father proving his good intentions by contributing time and effort to the relationship, highlighting the implicit significance of labor theory

150. Reber v. Reiss, 42 A.3d 1131, 1134 (Pa. Super. Ct. 2012) ("[W]e conclude that Wife's compelling interests in using the pre-embryos include the fact that these preembryos are the option that provides her with what is likely her only chance at genetic parenthood and her most reasonable chance for parenthood at all."); Davis v. Davis, 842 S.W.2d 588, 604 (Tenn. 1992) ("Ordinarily, the party wishing to avoid procreation should prevail, assuming that the other party has a reasonable possibility of achieving parenthood by means other than use of the preembryos in question. If no other reasonable alternatives exist, then the argument in favor of using the preembryos to achieve pregnancy should be considered.").

151. See Ruth Colker, Pregnant Men Revisited or Sperm Is Cheap, Eggs Are Not, 47 HASTINGS L.J. 1063, 1066 (1996).

152. See id. at 1071; Tracey S. Pachman, Disputes Over Frozen Preembryos \& the "Right Not to Be a Parent," 12 ColuM. J. GENDER \& L. 128, 145 (2003) ("Because reproduction biologically takes place exclusively within a woman's body, any process that must take place outside a woman's body in the IVF procedure requires considerable contributions by the woman."). 
in current doctrine. ${ }^{153}$ Moreover, when the thread of labor is highlighted, it becomes clearer that unwed biological fathers have fewer paths to legal parenthood available to them than do unwed biological mothers, whose parentage is assumed.

In Stanley v. Illinois, the first case in which the Court dealt with the legal treatment of unwed biological fathers, a father challenged an Illinois statute that specified upon the death of a mother of illegitimate children, the children were made wards of the state. ${ }^{154}$ The plaintiff, Peter Stanley, had lived with his children and helped to raise them for their whole lives, yet the statute gave him no opportunity to argue that staying in his care was in their best interest. ${ }^{155}$ One way to understand the statute's effect, therefore, was to regard all unwed fathers as unfit, which would justify taking Stanley's children away from him. ${ }^{156}$

As an alternative, however, the Court took the view that "Stanley [was] treated not as a parent but as a stranger to his children." ${ }^{157}$ In effect, the statute manifested a "theory that an unwed father is not a 'parent' whose existing relationship with his children must be considered." "58 The Court therefore held that the statute was unconstitutional, as Stanley was entitled to show that he was not neglectful, was an active parent, provided caretaking, and deserved custody. ${ }^{159}$ The Court thus found that unwed biological fathers had the right to show that they were "real" fathers. ${ }^{160}$ Importantly, however, the Court seemed to have in mind evidence of Stanley's parental labor as the type of evidence that he could present to prove that he had parental rights. ${ }^{161}$

Six years later, the Court decided Quilloin $v$. Walcott, which gave voice to the assumption that parental labor was what converted an unwed biological father to a legal father. ${ }^{162}$ The biological father, Leon Webster Quilloin, had informally acknowledged his son, and although he never lived with the child and biological mother as a

153. See, e.g., Lehr v. Robertson, 463 U.S. 248 (1983); Caban v. Mohammed, 441 U.S. 380 (1979); Quilloin v. Walcott, 434 U.S. 246, 255-56 (1978); Stanley v. Illinois, 405 U.S. 645, 654-655 (1972).

154. Stanley, 405 U.S. at 646.

155. Id. at 646-47.

156. Id.

157. Id. at 648 .

158. Id. at $649-50$ (emphasis added).

159. Id. at $649,654-55$.

160. Id. at 657-58.

161. See id. at 654-55 ("N]othing in this record indicates that Stanley is or has been a neglectful father who has not cared for his children.").

162. Quilloin v. Walcott, 434 U.S. 246, 255-56 (1978). 
family, he visited and gave gifts to his son. ${ }^{163} \mathrm{He}$ never formally legitimated his paternity through a court order, apparently because he was unaware that such proceedings were available. ${ }^{164}$ When the child was three years old, the mother married a man who later petitioned to adopt the child. ${ }^{165}$ Under state law, only the consent of the mother was necessary to move forward with the adoption, even though the adoption would foreclose any parental rights of the biological father. ${ }^{166}$

When presented with the issue, the Court gave considerable attention to which man had created a family with the child, describing the stepfather as "part of the family unit in which the child was in fact living" ${ }^{67}$ and the proposed adoption as "giv[ing] full recognition to a family unit already in existence." 168 By contrast, Quilloin had not had actual custody of his child, nor had he sought custody. ${ }^{169}$ Occasional visits and financial support were outweighed, in the Court's mind, by the everyday fathering performed by the child's stepfather; Quilloin had failed to gain parental rights and status. ${ }^{170}$ Interestingly, although the child's stepfather had to legally adopt the child, in one sense the Court recognized the stepfather's caretaking labor as transferring to himself what was at least initially Quilloin's opportunity to formalize his status as father. Parental labor was thus significant in transferring parental status from Quilloin to the stepfather.

One year later, Caban v. Mohammed again raised a contested stepparent adoption in a context that made explicit the centrality of an unwed father's labor. ${ }^{171}$ The biological parents, Abdiel Caban and Maria Mohammed, lived together for five years and represented themselves as a married couple (the two could not legally marry as Caban was separated, but not divorced, from another woman). ${ }^{172}$ These years encompassed the first four years of their son's life and the first two years of their daughter's life. ${ }^{173}$ Caban was listed on the children's birth certificates, and they lived as a unitary family. ${ }^{174}$ The family unit dissolved when Mohammed moved with her children to

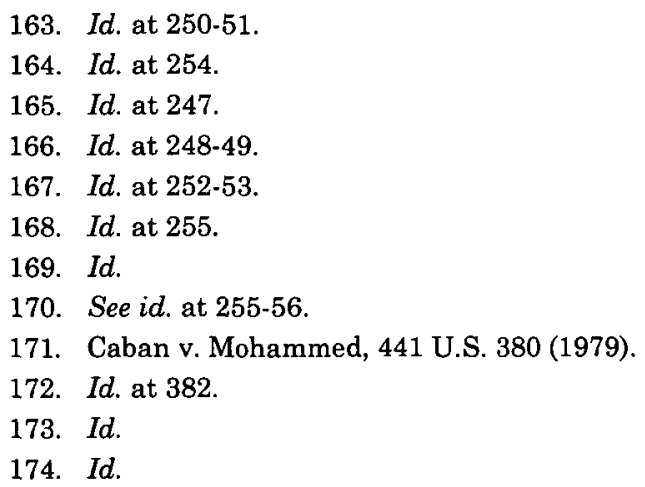


live with another man, whom she married one month later. ${ }^{175}$ For the first few years of his children's lives, however, Caban had contributed significant caretaking work. ${ }^{176}$

The dispute arose when Mohammed sent the children to Puerto Rico with her mother. Caban went to Puerto Rico to visit the children and, without warning or consent, took the children back to New York. ${ }^{177}$ Possibly in response, Mohammed's husband (the children's stepfather) then filed a petition to adopt the children. ${ }^{178}$ In turn, Caban-who, since he and Mohammed had broken up, had secured a divorce from his first wife and married his next girlfriend-filed a cross-petition with his new wife not only opposing Mohammed's stepparent adoption, but also asking that Caban's wife instead be allowed to adopt the children, terminating Mohammed's status as legal mother. ${ }^{179}$

Despite the mirror-image claims brought by Caban and Mohammed, New York law viewed the claims differently. In order to complete the adoption process, any stepmother wishing to legally adopt her stepchildren was required to secure the consent of the biological mother. ${ }^{180}$ In contrast, although Caban as biological father had a right to be heard as part of the proceedings-a lesson learned from Stanley - his consent was not required. ${ }^{181}$ This placed unwed biological fathers alongside parents whose legal status had been terminated, either because they relinquished the child or because they were declared unfit. ${ }^{182}$

The Court held that the gendered classification was unconstitutional under the Equal Protection Clause. ${ }^{183}$ Notably, its reasoning was grounded in Caban's everyday caretaking work:

The present case demonstrates that an unwed father may have a relationship with his children fully comparable to that of the mother. Appellant Caban, appellee Maria Mohammed, and their two children lived together as a natural family for several years. As members of this family, both mother and father participated in the care and support of their children. There is no reason to believe that the Caban children-aged 4 and 6 at the time of the adoption

175. Id.

176. Id.

177. Id. at $382-83$.

178. Id. at 383 .

179. Id.

180. Id. at 385.86 .

181. Id. at 384 .

182. Id. at $385-87$.

183. Id. at 382 . 
proceedings-had a relationship with their mother unrivaled by the affection and concern of their father. ${ }^{184}$

The Court went further to specify that where the father had not "par. ticipate[d] in the rearing of his child, nothing in the Equal Protection Clause precludes the State from withholding from him the privilege of vetoing the adoption of that child." ${ }^{185}$ Caban's status as father thus turned entirely on being an active participant in the everyday raising of his children-his parental labor.

Even the dissents from the Court's opinion focused on the distinction between biology and labor. Justice Stewart, for example, explicitly rejected the bodily unity theory that parental status is generated through genetic connection, stating that "[p]arental rights do not spring full-blown from the biological connection between parent and child." ${ }^{186} \mathrm{He}$ went on to acknowledge the labor interest of the mother; a mother "carries and bears the child, and in this sense her parental relationship is clear." ${ }^{187}$ By contrast, the biological father's parental status could be shown by an "actual relationship between father and child." 188 Justice Stevens also highlighted the mother's greater work in caring for the child: "Only the mother carries the child; it is she who has the constitutional right to decide whether to bear it or not." ${ }^{189}$ Even after birth, Justice Stevens believed "it is virtually inevitable that from conception through infancy the mother will constantly be faced with decisions about how best to care for the child, whereas it is much less certain that the father will be confronted with comparable problems." $190 \mathrm{He}$ would hold that because "newborn infants and very young children in the custody of their natural mothers" were the typical subjects of adoption petitions by stepparents, this self-evidently demonstrated the greater parental claim of mothers than fathers. ${ }^{191}$

Justice Stevens gave further voice to these beliefs when he wrote the Court's opinion in the final unwed father case, Lehr v. Robertson. ${ }^{192}$ His statement of the issue presented by the case betrayed its resolution: "whether New York has sufficiently protected an unmar-

184. Id. at 389 (footnote omitted).

185. Id. at 392 .

186. Id. at 397 (Stewart, J., dissenting).

187. Id.

188. Id

189. Id. at 404 (Stevens, J., dissenting).

190. Id. at 406 .

191. See id. at 410.

192. Lehr v. Robertson, 463 U.S. 248 (1983). 
ried father's inchoate relationship with a child whom he has never supported and rarely seen in the two years since her birth." ${ }^{193}$

What Justice Stevens did not acknowledge, but Justice White pointed out, was that the reason that the unmarried father's relationship was inchoate was that the mother had prevented the relationship from developing further. ${ }^{194}$ As summarized in the introduction, White's dissent noted approvingly that Jonathan Lehr lived with Lorraine Robertson throughout her pregnancy, and Lehr visited her every day in the hospital after she gave birth. ${ }^{195}$ When she was discharged with their daughter Jessica, however, she concealed her location from Lehr, who only tracked her down with the assistance of a private detective. ${ }^{196}$ By that time, she had married Richard Robertson, who petitioned to adopt Jessica when she was two years old. ${ }^{197}$

Justice Stevens, by contrast, did not explain the factual background giving rise to the case, and instead turned to Justice Stewart's dissent from Caban, quoting and italicizing for emphasis the idea that " " $[p]$ arental rights do not spring full-blown from the biological connection between parent and child. They require relationships more enduring." "198 The test for constitutional protection of the parental relationship between unwed biological father and child, Justice Stevens concluded, required both a biological link and the father's " 'com[ing] forward to participate in the rearing of his child." "199 The biological connection was an opportunity to develop a parental relationship but did not create the parental relationship itself. ${ }^{200}$

Although the Court has not been faced with another case presenting the claims of unwed biological fathers in the context of family law, it has reinforced the reliance on relationships as parentage in the context of citizenship and immigration. Federal law specifies different paths to U.S. citizenship for a child born out of the country to one citizen parent and one noncitizen parent. If the child's father is the American citizen, he must formally codify his paternity by legitimating the child according to the laws of the child's residence, signing a statement under oath acknowledging his paternity, or securing

193. Id. at 249-50.

194. Id. at 269, 271 (White, J., dissenting).

195. Id. at 268-69.

196. Id. at 269 .

197. Id. at 250 (majority opinion).

198. Id. at 260 (quoting Caban v. Mohammed, 441 U.S. 380,397 (1979) (Stewart, J., dissenting)).

199. Id. at 261 (alteration in original) (quoting Caban, 441 U.S. at 392).

200. Id. Multiple commentators have criticized Lehr's treatment of the constitutional rights of fathers. See, e.g., Elizabeth Buchanan, The Constitutional Rights of Unwed Fathers Before and After Lehr v. Robertson, 45 OHIO ST. L.J. 313 (1984); Jeffrey A. Parness \& Zachary Townsend, Legal Paternity (and Other Parenthood) After Lehr and Michael H., 43 U. TOL. L. REV. 225 (2012). 
a court order declaring his paternity. ${ }^{201}$ If the American citizen parent is the mother, she need not take such additional steps. ${ }^{202}$ In 2000 , Tuan Anh Nguyen, the child of an American citizen father and Vietnamese mother who had lived with his father in the United States since he was six years old, challenged the law when he faced deportation after being convicted of sexual assault on a child. ${ }^{203}$

In upholding the statute, the Court gave two justifications for the additional requirements placed upon fathers in order to bestow their citizenship on their child. One was to insure that a biological relationship between parent and child did exist: while it could be assumed in the case of the mother, the Court held that a father could fairly be required to at least formally state his relationship. ${ }^{204}$ (Justice O'Connor, writing in dissent, pointed out that a separate provision not challenged by Nguyen required that fathers show " a blood relationship between the [alleged child] and the father . . . by clear and convincing evidence," making this justification redundant at best. ${ }^{205}$ ) A biological relationship, therefore, was a threshold requirement for transferal of citizenship.

The second reason added a parallel requirement of some kind of parental labor-or at least potential labor. In contrast to the standard of an extant substantial relationship applied to unwed biological fathers seeking legal parentage, the Court viewed the formal legitimizing requirement as a means

to ensure that the child and the citizen parent have some demonstrated opportunity or potential to develop not just a relationship that is recognized, as a formal matter, by the law, but one that consists of the real, everyday ties that provide a connection between child and citizen parent and, in turn, the United States. ${ }^{206}$

The focus on the opportunity for a relationship, rather than on proving the existence of an actual relationship, points to a few interesting implications. As Justice O'Connor pointed out, the interest in ensuring that only those children who have become "American" in some way are able to gain citizenship is not served well by the requirements at issue. ${ }^{207}$ Nguyen, after all, had grown up in the United States in the care of his American citizen father. ${ }^{208}$ Despite the undisputed presence of the actual relationship described by the

201. Nguyen v. INS, 533 U.S. 53, 59 (2001).

202. Id. at $59-60$.

203. Id. at 57 .

204. Id. at 62-64.

205. Id. at 80 (O'Connor, J., dissenting) (quoting 8 U.S.C. $\S 1409(\mathrm{a})(1)$ (1994)).

206. Id. at 64-65 (majority opinion).

207. Id. at 83-85 (O'Connor, J., dissenting).

208. Id. at 85 . 
Court-as well as long-term domestic residency, which went above and beyond the law's requirements ${ }^{209}$-his father's failure to fill out paperwork before Nguyen's eighteenth birthday doomed his citizenship request. ${ }^{210}$

A final example highlights the precarious position of unwed biological fathers. In the 1984 case Michael H. v. Gerald D., the Supreme Court was faced with facts that combined biological, marital, and functional theories of parenthood. ${ }^{211}$ Michael $\mathrm{H}$. had an affair with his neighbor Carole D., who was married to Gerald D. ${ }^{212}$ Michael and Carole's affair produced a daughter, Victoria, but "Gerald was listed as father on the birth certificate." ${ }^{13}$ During the first three years of Victoria's life, she spent periods of time living with Gerald, Michael, and a third man with whom Carole had a relationship. ${ }^{214}$ Both Gerald and Michael treated Victoria as their own child and held her out as their child publicly. ${ }^{215}$ After Carole reconciled with Gerald, Michael sought a legal declaration of paternity and visitation rights with Victoria. ${ }^{216}$ Under California state law, however, Gerald was presumed to be Victoria's legal father, subject only to rebuttal by either the husband or mother. ${ }^{217}$ California law thus denied Michael the opportunity to present evidence regarding his relationship with Victoria. Michael challenged the state statute as violations of both procedural and substantive due process. ${ }^{218}$ Citing the Supreme Court's line of unwed father cases, Michael argued that he could show both that he was Victoria's biological father and that he had created a substantial parent-child relationship with her, and thus was entitled to protection of his relationship, or at the very least a hearing at which he could present evidence as to his paternity. ${ }^{219}$

The Court rejected his argument. In the eyes of the Court, the previous cases did not depend upon a biological and substantial relationship in isolation, but rather "the historic respect-indeed, sanctity would not be too strong a term-traditionally accorded to the relationships that develop within the unitary family." 220 The question at issue was thus not whether California's statute was refusing to give

209. Id.

210. See id. at 61-62 (majority opinion).

211. Michael H. v. Gerald D., 491 U.S. 110 (1989).

212. Id. at 113 .

213. Id. at 113-14.

214. Id. at 114 .

215. Id. at 113-14.

216. Id. at 114 .

217. Id. at $117-18$.

218. Id. at 116 .

219. Id. at 119.

220. Id. at 123 . 
adequate procedural or substantive protections to Michael's parental relationship, but whether there was a relationship at all-in the words of Justice Scalia writing for the Court, "whether the relationship between persons in the situation of Michael and Victoria has been treated as a protected family unit under the historic practices of our society." ${ }^{221}$ As might be predicted from the question, the Court answered in the negative. ${ }^{222}$

Interestingly, both concurrences and dissents authored by other Justices turned on the question of Michael's relationship with Victoria. Although Justice Stevens concurred in the Court's judgment, he wrote separately to emphasize that the Court's past cases, citing Stanley and Caban, "demonstrate[d] that enduring 'family' relationships may develop in unconventional settings." ${ }^{223} \mathrm{He}$ concluded, however, that Michael had an adequate opportunity under the California law to establish his relationship. ${ }^{224}$ By contrast, both Justice Brennan and Justice White dissented on the basis that any unwed biological father who had created a substantial parent-child relationship had a constitutional liberty interest in his parental status. ${ }^{225}$

\section{Implications}

Unwed fathers thus must meet two separate requirements in order to have a constitutional parental right. First, they must have a genetic link to the child in question. Second, they must create a relationship with the child, investing labor into their parental status. There are obvious tangible consequences to this regime. Unwed fathers are put at a disadvantage as compared to unwed mothers and married parents for the span of time when the unwed father has not yet been able to build a relationship with his child. This could either be because the child is too young, the child has not yet been born, or the father has been unable to contact his child due to actions of the mother. The Supreme Court has not yet spoken to the problems that Laura Oren labels "advanced Lehr line-drawing,"226 except to the extent that the majority opinion in Lehr was implicitly unconcerned with Lehr's inability to find his child in order to create a substantial relationship.

In the years since Lehr, however, new practices meant to protect children have unintentionally exacerbated potential problems for

221. Id. at 124 .

222. Id.

223. Id. at 133 (Stevens, J., concurring).

224. Id.

225. See id. at 142-43 (Brennan, J., dissenting); id. at 157-58 (White, J., dissenting).

226. Laura Oren, Thwarted Fathers or Pop-Up Pops?: How to Determine When Putative Fathers Can Block the Adoption of Their Newborn Children, 40 FAM. L.Q. 153, 159 (2006). 
new unwed fathers. For example, at the turn of the twenty-first century the public's attention was captured by a series of stories about abandoned and/or murdered newborns, most colorfully embodied by a teenager attending her high school prom who gave birth in a bathroom, put the baby in the trash, and returned to the dance. ${ }^{227}$ Aiming to give such mothers an option to relinquish the child rather than kill and discard it, almost every state passed some form of a safe haven law, under which a child's parent may anonymously leave the infant at specific locations without exposing oneself to potential abandonment or other criminal charges. ${ }^{228}$ An obvious consequence of the anonymity generally provided to the abandoning parent, nearly always the child's mother, is that it is difficult if not impossible to ensure that the child's father consented or was aware of the relinquishment. ${ }^{229}$ Multiple scholars have criticized safe haven laws as creating "thwarted fathers by legal design who do not enjoy even a modicum of procedural due process." 230

In addition to the concrete problems created by the current constitutional understanding of father's rights, broader conceptual issues arise when viewing the issue through the lens of how parental rights are acquired. One way of reading Supreme Court doctrine is to conclude that the prebirth labor of unwed fathers is not recognized or credited in establishing their parental rights. Further examination of the postbirth labor, however, demonstrates that unwed fathers do not have any Lockean labor path into parenthood. Requiring a substantial relationship with the child is a functional requirement: it is justified by the child-centric concern of protecting those relationships that are important to the child. Although functional doctrines of legal parentage overlap with a labor-based theory, a true labor-based theory would view a man as earning his status of father through labor for the benefit of the child.

227. See Carol Sanger, Infant Safe Haven Laws: Legislating in the Culture of Life, 106 COLUM. L. REV. 753, 754 (2006). For an in-depth discussion of the psychological characteristics of young mothers who commit neonaticide, or killing one's child within twenty-four hours of birth, see Shannon Farley, Comment, Neonaticide: When the Bough Breaks and the Cradle Falls, 52 BUFF. L. REV. 597 (2004).

228. See Jeffrey A. Parness \& Therese A. Clarke Arado, Safe Haven, Adoption and Birth Record Laws: Where Are the Daddies?, 36 CAP. U. L. REv. 207, 212-13 (2007).

229. See id. at 211-13; see also Jeffrey A. Parness, Adoption Notices to Genetic Fathers: No to Scarlet Letters, Yes to Good-Faith Cooperation, 36 CUMB. L. REv. 63, 71 (2005).

230. Oren, supra note 226, at 189; see also Jeffrey A. Parness, Deserting Mothers, Abandoned Babies, Lost Fathers: Dangers in Safe Havens, 24 QUINNIPIAC L. REV. 335 (2006); Jeffrey A. Parness, Lost Paternity in the Culture of Motherhood: A Different View of Safe Haven Laws, 42 VAL. U. L. REV. 81 (2007); Parness \& Arado, supra note 228; Jeffrey A. Parness, Systematically Screwing Dads: Out of Control Paternity Schemes, 54 WAYNE L. REV. 641 (2008); Lucinda J. Cornett, Note, Remembering the Endangered "Child": Limiting the Definition of "Safe Haven" and Looking Beyond the Safe Haven Law Framework, $98 \mathrm{KY}$. L.J. 833 (2010). 
A biological father's rights are thus fundamentally relational, turning either on his relationship with the biological mother or with the child. The only way for a man to ensure parental rights before birth is to marry the biological mother, a marriage-based classification that the Supreme Court has explicitly held raises no equal protection concerns. ${ }^{231}$ And the only way for an unwed man to ensure parental rights after birth is to create a functional relationship with the child, which is dependent on the biological mother's willingness to allow such a bond to develop. ${ }^{232}$

This reinforces a view of men as, at best, occasional parents. Nancy Dowd summarized the Supreme Court's language as reflecting "social disdain for unmarried fathers" 233 and the doctrine as "grounded in gender assumptions that women naturally parent, while men, outside of marriage, choose to parent or not, and nearly always choose not to do so." ${ }^{234}$ Mothers are viewed as the primary parent, both in terms of work and a more intangible conception of parenting as self-sacrifice; the mother is "the parent who performs the bulk of childcare, the parent who cares enough to give up herself." 235

This narrative not only depends upon women being more suited to be parents, however-it also relies upon a deep-seated assumption that men do not want, perhaps should not want, to take on the nurturing and emotional work of parentage. Susan Frelich Appleton analyzed the Supreme Court's recent language on abortion as expressing "disapproval of deviation" from the dominant understanding that "men seek to avoid parenthood and all attendant responsibilities, both emotional and material, while women harbor such a powerful desire to mother that they are willing to take these men to court if necessary to achieve that goal." ${ }^{236}$ Nurture is seen as fundamentally "unmanly." 237 In a self-fulfilling cycle, these beliefs are used to justify policies that make it even harder for men to be active parents. In 1992, for example, Mary Becker described "a conspiracy of silence forbid[ding] discussion of what is common knowledge: mothers are usually emotionally closer to their children than fathers," before using that common knowledge to argue for a strong deference to moth-

231. E.g., Quilloin v. Walcott, 434 U.S. 246, 256 (1978).

232. Lehr v. Robertson, 463 U.S. 248, $269-71$ (1983) (White, J., dissenting).

233. Nancy E. Dowd, Fathers and the Supreme Court: Founding Fathers and Nurturing Fathers, 54 EMORY L.J. 1271, 1297 (2005).

234. Id. at 1310 .

235. Darren Rosenblum, Unsex Mothering: Toward a New Culture of Parenting, 35 HARV. J.L. \& GENDER 57, 67 (2012).

236. Susan Frelich Appleton, Reproduction and Regret, 23 YALE J.L. \& FEMINISM 255, 325 (2011).

237. Nancy E. Dowd, Masculinities and Feminist Legal Theory, 23 WIS. J.L. GENDER \& SOC'Y 201, 239 (2008). 
er's choices in custody disputes. ${ }^{238}$ Although Becker's proposal was not adopted formally, there is strong evidence that custody decisions are strongly biased toward granting custody to mothers rather than fathers. ${ }^{239}$ Mothers are often offered more parental leave than fathers, ${ }^{240}$ and men who are offered and take parental leave are viewed unfavorably by their employers. ${ }^{241}$ Even the Supreme Court acknowledged such inequalities in Nevada Department of Human Resources $v$. Hibbs, remarking that "[s]tereotypes about women's domestic roles are reinforced by parallel stereotypes presuming a lack of domestic responsibilities for men. Because employers continued to regard the family as the woman's domain, they often denied men similar accommodations or discouraged them from taking leave." 242

The doctrinal non-recognition of father's parental labor, therefore, has broad implications for the constitutional status of fathers, balance in parenting, and gender stereotypes outside of the home. In the next Part, I propose that greater recognition of parental labor, even prebirth labor, be incorporated into parentage laws.

\section{LABOR-BASED THEORIES INTO DOCTRINE}

Prebirth parental labor performed by unwed biological fathers should be understood as fulfilling the extant "substantial relationship" requirement. Current doctrine, as summarized above, requires both a biological relationship plus a significant personal relationship between the unwed father and the child before the father's status as parent is constitutionally recognized. I argue that prebirth labor fulfills the same goals as the substantial relationship test, by providing tangible proof that the father intends to be an active and engaged parent.

Prebirth labor is also a more concrete method of understanding and recognizing intent in a context where explicit intent is rare. Prebirth labor is not a functional theory of parentage; functional theories turn on the psychological significance of existing relationships and are justified through explicit concern for the child's well-being. Intent, by contrast, has a more attenuated connection to the child's well-being. My proposed prebirth labor test thus operationalizes intent as a parentage rule.

238. Becker, supra note 32 , at 137.

239. See Solangel Maldonado, Beyond Economic Fatherhood: Encouraging Divorced Fathers to Parent, 153 U. PA. L. REV. 921, 967-75 (2005).

240. See David K. Haase, Evaluating the Desirability of Federally Mandated Parental Leave, 22 FAM. L.Q. 341, 360 (1988).

241. See Nancy Levit, Feminism for Men: Legal Ideology and the Construction of Maleness, 43 UCLA L. REV. 1037, 1073-74 (1996).

242. Nev. Dep't of Human Res. v. Hibbs, 538 U.S. 721, 736 (2003). 
Many of the proposals implementing intent to be a parent provide standard rules and procedures that require clear expression of that intent-for example, in writing in the context of ART, where written agreements are already in use. ${ }^{243}$ In contrast, I propose prebirth labor as a subcategory of intent: a way to make intent clearer in a setting in which written arrangements are rare, and where the law is already concerned with the intent of an unwed father to seize the opportunity of parenthood to build a significant relationship.

\section{A. Mechanics}

I define prebirth parental labor as actions undertaken that prepare for the birth of the child and plan for future caretaking work. Although by no means an exhaustive list, examples of prebirth parental labor performed by a biological father include the following:

- Requesting paternity leave.

- Requesting future accommodations in work schedule or duties to accommodate childcare, such as requesting specific shift schedules or reducing overtime hours.

- Actions that are aimed at reducing safety risks to the child, such as quitting smoking or baby-proofing a residence.

- Planning childcare arrangements, such as contacting a daycare near his home or childcare affiliated with his employment.

- Prospectively signing a child up for his insurance.

- Educating himself about childcare, such as enrolling in a parenting class (with or without the biological mother).

- Taking steps to list the child on benefits such as insurance plans.

- Buying parenting supplies such as diapers, baby wipes, or a crib.

- Setting up a nursery in his residence.

- Establishing a savings account or trust for the child.

- Going to prenatal or childbirth classes and appointments with the biological mother.

- Drawing up a preliminary parenting and custody schedule with the biological mother.

Some of the examples given above require that the father have significant funds available to him or depend upon an amicable relationship between the biological father and mother. Although such actions should be recognized as prebirth parental labor, money or an amicable relationship should not be required. Thus, a father with limited

243. Purvis, supra note 27, at 212. 
funds who does not have a cooperative relationship with the biological mother should nonetheless have options such as a free local parenting class and setting up a thrift-store crib in one corner of his bedroom open to him.

The labor of a biological father, in other words, need not be done with the mother's permission. To the extent that the current requirement of a substantial relationship cannot in practice be met without the cooperation of the mother, by allowing contact between the child and biological father, this removes an obstacle to unwed biological fatherhood. This shift will address the Lehr example of thwarted fathers, ${ }^{244}$ by allowing a father to take independent actions to secure his parental status even if the biological mother intends or attempts to hinder his plans.

Furthermore, such actions must be taken with the intent to be a parent. For example, a man who moves in with a new girlfriend, who herself has a young child, cannot cite a nursery in the new girlfriend's apartment as evidence of his own prebirth parental labor. As will be discussed further below, if recognition of parental labor is extended beyond the context of unwed prebirth biological fathers, this aspect of the intent requirement prevents accidental acquisition of parental status by nannies or other persons who perform caretaking work without any intention of being recognized as legal parents.

Finally, I propose assessing the presence of a "substantial" amount of prebirth parental labor. This is necessary in order to ensure that a trivial gesture-the purchase of a single box of diapers, for example-does not give the prebirth father an easier path to parenthood than the postbirth father, and to treat acquisition of parental status with the gravity it deserves. A "substantial" amount of labor cannot be easily quantified, but the guiding principle should be labor sufficient to show that the father is apparently preparing to serve as primary caretaker for the child for significant periods of time.

The procedure for asserting status as legal parent would be the same as for past claimants such as Peter Stanley, Mohammed Caban, or Jonathan Lehr: determination of legal parentage would be a threshold determination at the beginning of a custody or visitation claim. Legal parentage can be understood as standing for custody, visitation, or blocking an adoption that would terminate parental status. Status as legal parent gives a person the ability to seek custody and visitation, but the actual custody determination is determined by assessing what would be in the child's best interest. ${ }^{245}$ Recognition as

244. See supra Part III.D.

245. A minor complication to this rule is statutes that recognize functional parents as something more than a legal stranger, but something less than a legal parent. 
a legal parent, therefore, would not guarantee custody or any visitation rights with the child.

\section{B. Broader Implications}

As explained above, I propose that prebirth parental labor be understood as fulfilling the "substantial relationship" required in addition to a biological link in order for an unwed biological father to have status as parent. This would treat the substantial relationship requirement as akin to the explanation given in Nguyen that the real concern is for a father who will take advantage of the opportunity to build a relationship with his child. ${ }^{246}$

\section{Married Biological Fathers}

The natural next question is whether parental labor should be recognized for existing children as well-that is, whether postbirth parental labor without the child present should be recognized as a labor-based theory of parentage that similarly triggers parental status. On the one hand, this would provide a more equitable answer for fathers such as Jonathan Lehr, who was eager for a relationship with his child but could not create one due to the biological mother's actions. ${ }^{247}$ On the other hand, there are obvious problems with the biological father of a ten-year-old child suddenly developing an interest in exercising parental rights. The potential parental rights of the adults must be balanced with the child's interest in stability. Although two parents are arguably better than one, one parent with settled legal rights may be better than one parent and one potential but unrecognized parent.

A natural limiting principle can be found in existing parental statutes. For example, a similar dilemma is created in the context of the marital presumption. On the one hand, as demonstrated in $\mathrm{Mi}$ chael $H$. v. Gerald $D$., an extremely strong marital presumption can have the perverse effect of shutting out an unmarried biological and functional father. ${ }^{248}$ On the other hand, if the presumed marital father is willing to raise the child as his own, it could harm the child to allow the biological father to claim legal fatherhood at any point before the child turned eighteen. One solution to this, as implemented by the Uniform Parentage Act, is to impose a statute of limitations of two years after the child's birth. ${ }^{249}$ If the biological father does not

246. See Nguyen v. INS, 533 U.S. 53, 64-65 (2001).

247. See supra text accompanying notes 192-200.

248. See supra text accompanying notes 211-25.

249. UNIF. PARENTAGE ACT $\S 607$ (a) (2000) (amended 2002). 
bring proceedings during that time, the presumed marital father's status cannot be challenged. ${ }^{250}$

I would adopt this standard, with the modification that if an unwed biological father asserts parental status using parental labor and has not had significant contact with the child, he must show that the reason for the lack of a relationship was reasonably beyond his control. Although I propose that unwed biological fathers be recognized as legal fathers without requiring the consent of the biological mother, that does not justify failing to attempt to engage in cooperative parenting, at least to the extent that the father takes on caretaking labor and begins to build a relationship with the child. If the unwed biological father asks the mother for time with the child and is denied, that should not be held against him in the determination of his legal status. ${ }^{251}$ Neither should circumstances that prevent his contact with the child, such as a father who is an active member of the military. Biological fathers who refuse to make good faith efforts, however-a father who voluntarily accepts a job across the country when he could reasonably be expected to find employment closer to the child, or who refuses to compromise with the mother in setting times for him to care for the child-cannot point to labor without the child present to satisfy the parental labor requirement postbirth.

\section{Wider Applications: Intent-Based Parentage}

One solution to recognizing the parental status of nonbiological and nonpregnant persons is to recognize the intent to be a parent as itself a rule of parentage. First arising in the context of assisted reproductive technologies, intent has been proposed as a freestanding rule of parentage. In other words, intent alone could create status as legal parent, regardless of genetic connection to the child or future child. John Lawrence Hill, one of the earliest proponents of intent as a rule, offered three primary justifications: the "but-for argument" that intent recognizes the persons without whom the child would not have been created, ${ }^{252}$ the contractual argument that the original agreements of all participants in an ART pregnancy should be en-

250. Id. The statute of limitations is not applied if the presumed father and biological mother were neither cohabitating nor sexually active during the probable time of the child's conception or if the presumed father has never publicly acknowledged and treated the child as his own. Id. $\S 607(\mathrm{~b})$.

251. Because custody and visitation decisions would still be made using the best interest of the child standard, however, such fathers would likely be at a disadvantage if a custody suit sought to substantially interfere with the child's settled family life.

252. Hill, supra note 26, at 414-15 ("What is essential to parenthood is not the biologi. cal tie between parent and child but the preconception intention to have a child, accompanied by undertaking whatever action is necessary to bring a child into the world." (emphasis in original)). 
forced, ${ }^{253}$ and the avoiding-uncertainty argument that intent provides the clearest prebirth answer to parentage..$^{254}$

In recent years, intent has been more fully explored as a parentage rule that provides a practical and more equitable solution in many contexts. In a previous article, I explored the normative advantages to intent, arguing that it facilitates and encourages responsible parenting. ${ }^{255}$ Such analysis considers intent as a freestanding rule to be added and incorporated into existing rules. ${ }^{256}$ Consideration of intent through the theoretical lens of property acquisition further illuminates the potential of intent, as well as broadens how intent might be implemented.

It is clear that intent has no connection to the bodily unity theory of parentage; intent is entirely divorced from considering biological connection between potential parent and child. Indeed, intent is often proposed as a rule that justifies disregarding the genetic connection between egg and sperm donors and resulting children. ${ }^{257}$ Therefore, intent can be understood as part of the move away from the bodily unity theory of parentage.

Because intent is often understood and justified in contractual terms, the Lockean labor theory may not initially seem to be a substantially better fit. One criticism of intent, particularly when it is implemented through private agreements that resemble contracts, is that it is effectively contracting to sell, or at least transfer, a child. The plan to raise a child, however, is planning to perform parental labor. As I previously explained, in the context of describing the potential emotional trauma to intended parents who are not given the child they have been anticipating,

[t]he intended parents plan for a child at least as long as parents who reproduce through traditional means-even longer, to the extent that finding gamete donors and a surrogate and then waiting through the preparation and medical procedures is a longer period of "trying to conceive" than traditional sexual reproduction. Throughout this time, intended parents invest financially in preparing for their child's arrival, plan to take maternity or paternity leave, and generally ready for their child's birth as any other parents would. Intended parents often support the surrogate not

253. Id. at 415-16 ("[T]he gestational host and the genetic progenitors should be held to their original promises not to seek any form of parental rights in the child.").

254. Id. at 417 ("Where the identity of the parents is not determined at the time of conception, all parties are affected adversely.").

255. See Purvis, supra note 27.

256. Id. at $230-41$.

257. See, e.g., Nancy D. Polikoff, A Mother Should Not Have to Adopt Her Own Child: Parentage Laws for Children of Lesbian Couples in the Twenty-First Century, 5 STAN. J. C.R. \& C.L. 201, 212-15 (2009); Richard F. Storrow, Parenthood by Pure Intention: Assisted Reproduction and the Functional Approach to Parentage, 53 HASTINGs L.J. 597 (2002). 
only financially through covering the costs of her pregnancy, but also participate in the pregnancy by attending doctor's visits with the surrogate. ${ }^{258}$

Intent, therefore, can be demonstrated through behavior. ${ }^{259}$ Moreover, the behavior is prebirth labor. Intent as a parentage rule thus is supported, at least in some forms, through a Lockean labor-based theory of parentage.

The labor-based theory of parentage thus has application outside of the context of biological fathers when applied as one form of intentbased theories. For example, parental labor and prebirth labor in particular illuminate the marital presumption. In one sense, the Lockean labor theory of parentage could be deployed to strengthen the marital presumption, by converting it from an outdated assumption regarding unknowable genetics to the recognition of marriage as acceptance and intent to parent the children born during the marriage. The labor theory, in other words, could treat marriage as a proxy for intent.

More interesting, however, is use of a labor theory of parentage as another reason to eliminate the marital presumption altogether. If parental labor underlies claims of parentage based both in genetics and in intent, the marital presumption may be redundant: one laborbased rule could apply to both married and unmarried fathers. Expansion of labor-based parentage as an intent-based theory divorced entirely from biological relationship would also create greater unification of parentage theory and rules between opposite-sex and samesex couples. As Nancy Polikoff points out, recent victories for the parenting claims of same-sex spouses have made "the parental status of a nonbiological mother dependent entirely upon her marriage to the biological mother." ${ }^{60}$ Polikoff argues that although employing the marital presumption in states that permit same-sex marriage may lead to victory in individual cases, it will create a growing gap between children whose parents marry, and thus whose family unit receives legal protection, and children whose parents either cannot or

258. Id. at 238 .

259. Notably, some scholars would treat intent and behavior as two separate categories. For example, Alicia Brokars Kelly recently proposed economic sharing behaviors as a test to identify intimate partners as an economic unit specifically in contrast to intent or consent-based tests. See Alicia Brokars Kelly, Navigating Gender in Modern Intimate Partnership Law, 14 J.L. \& FAM. STUD. 1, 45 (2012) ("It is true that commitment often does shape economic behavior: as I have said, more committed partners are more likely to share economic resources. However, levels of commitment are difficult to ascertain, vary across couples and in any event can change and even be abandoned. Moreover, it is behavior that directly shapes the financial situation of the family and of each partner. The standard I propose is based on behavior and not intent.").

260. Nancy D. Polikoff, The New "Illegitimacy": Winning Backward in the Protection of the Children of Lesbian Couples, 20 AM. U. J. GENDER SOC. POL'Y \& L. 721, 723 (2012). 
choose not to marry. ${ }^{261} \mathrm{~A}$ labor-based understanding of intent can be consistently employed both before and after birth, can be used regardless of the sexual orientation of the parents, and provides the same results whether the parents are married or not.

Finally, a labor-based understanding of intent also offers promise for the more theoretical question of recognizing more than two parents. Although California Governor Jerry Brown recently vetoed a bill that would permit recognition of more than two legal parents, ${ }^{262}$ all fifty states currently cap formal recognition of legal parents at two. ${ }^{263}$ This limit has been criticized by a rich vein of legal scholar. ship, arguing that more than two parents would have myriad benefits for a child and would recognize complex family relationships that are currently unacknowledged by the law. ${ }^{264}$

A labor-based understanding of intent would support the possibility of more than two legal parents. The questions are distinct, but related: first, How should parentage be determined? Second, how many parents should there be? The answer to the first can determine the answer to the second: if your answer is that the genetic parents of a child should be identified as legal parents (at least if they are married), ${ }^{265}$ then your answer to the second will be two. If your answer to the first includes intent-based theories, by contrast, the answer to the second is wide open.

Incorporating a labor-based theory of intent provides new solutions to some of the criticisms of intent in the context of the number of legal parents. When intent is understood as analogous to a contract, the theory itself does not provide a limiting principle to the number of legal parents. Twenty people might sign an agreement

261. Id. at 722 .

262. Jim Sanders, Jerry Brown Vetoes Bill Allowing More Than Two Parents, SACRAMENTO BEE (Sept. 30, 2012, 1:22 PM), http://blogs.sacbee.com/capitolalertlatest/ 2012/09/jerry-brown-vetoes-bill-allowing-more-than-two-parents.html.

263. In states that recognize functional parents as having some legal rights and obligations, more than two people may have a legally cognizable relationship with the child. For example, Pennsylvania courts recently grappled with competing claims regarding the custody and child support obligations between three people: two women who had been in a nine-year relationship that produced four children and a male friend who acted as sperm donor to biologically father two of the children and had at least some role in raising them. Although the court recognized all three as indispensable parties to the proceedings, the three were described as two parents and one person with in loco parentis status. See Jacob v. Shultz-Jacob, 923 A.2d 473 (Pa. Super Ct. 2007).

264. See, e.g., Susan Frelich Appleton, Parents by the Numbers, 37 HofsTra L. REv. 11 (2008); Katharine K. Baker, Bionormativity and the Construction of Parenthood, 42 GA. L. REV. 649 (2008); Nancy E. Dowd, Multiple Parents/Multiple Fathers, 9 J.L. \& FAM. STUD. 231 (2007); Melanie B. Jacobs, Why Just Two? Disaggregating Traditional Parental Rights and Responsibilities to Recognize Multiple Parents, 9 J.L. \& FAM. STUD. 309 (2007); Laura T. Kessler, Community Parenting, 24 WASH. U. J.L. \& POL'Y 47 (2007).

265. See Lynn D. Wardle, The Disintegration of Families and Children's Right to Their Parents, 10 AVE MARIA L. REV. 1, 4 (2011). 
that they intend to collectively parent one child. This is in stark contrast to the California Supreme Court's reasoning, when faced with the prospect of recognizing one legal father and two legal mothers, that to acknowledge a second legal mother would necessarily diminish the rights of the first: parental rights as a limited resource ${ }^{266} \mathrm{La}$ bor, by contrast, admits at least the possibility of a maximum number of parents, in that although it may occasionally seem otherwise, the tasks of parenthood are not unlimited. Caretaking labor shared among twenty people would create twenty babysitters: parental labor must be a significant amount of labor, not an occasional shift.

\section{Potential Objections}

Apart from what I argue are compelling theoretical and practical reasons that support a labor-based understanding of intent, it is simple to identify a few constituencies or supportive perspectives for such a proposal, particularly as I propose it be employed in the context of unwed biological fathers. The fathers' rights movement is perhaps the most obvious, ${ }^{267}$ as well as movements advocating for nontraditional parents such as parents utilizing ART or same-sex parents. Supporters of child-centric approaches to parentage regimes might find common ground with the labor-based theory's goal of creating stable rules of parentage that make it easier for an engaged second parent to protect his legal rights. ${ }^{268}$

\section{Feminist Objections}

A particularly complex question is whether my proposal would or should be supported by feminists. Legal feminism could be defined most broadly as a vision of "true and substantive equality," 269 but different threads of feminist thought might view recognition of prebirth parental labor of unwed biological fathers as normatively quite different. It is my contention, however, that because my proposal at-

266. See Johnson v. Calvert, 851 P.2d 776, 781 n.8 (Cal. 1993).

267. See generally Richard S. Collier, The Fathers' Rights Movement, Law Reform, and the New Politics of Fatherhood: Some Reflections on the UK Experience, 20 U. FLA. J.L. \& PUB. POL'Y 65 (2009) (describing the British fathers' rights movement challenging child support and custody resolutions).

268. But cf. Bartlett, supra note 87 (urging states to reject exclusivity of parental status); Karen Czapanskiy, Volunteers and Draftees: The Struggle for Parental Equality, 38 UCLA L. REV. 1415 (1991) (proposing a new "equality ideology" of parenting that would ideally result in an equal division of parenting responsibilities); Barbara Bennett Woodhouse, Hatching the Egg: A Child-Centered Perspective on Parents' Rights, 14 CaRdozo L. REV. 1747 (1993) (arguing that recognition of parental rights by definition undermines a better definition of parenting as meeting children's needs).

269. Owen M. Fiss, The Death of the Law?, 72 CoRNELL L. REV. 1, 9 (1986) (contrasting to critical legal studies, where the aim of critique is critique, and saying attempts to construct affirmative programs are empty and unattractive). 
tacks stereotypes regarding men as less willing or less suited to be fathers, it is a feminist suggestion.

A brief (if superficial) outline of the various types of feminism is helpful for assessing the context into which my argument fits. Liberal feminism might be described as more concerned with classification than subordination: one characterization summarized liberal feminists in the 1980s as "argu[ing] that it is better to stress the similarities of men and women and to minimize the differences," so that men and women are governed by the same laws and rules. ${ }^{270}$ "By contrast, radical feminists argued against the assimilation that 'sameness' arguments tended to produce and called for equality theories that recognized gender differences." 271 Radical feminism might be further subdivided into more modern schools such as dominance feminism, voiced most strongly in the groundbreaking work of Catharine MacKinnon. ${ }^{272}$ MacKinnon viewed society and the law as fundamentally hierarchical; "the social relation between the sexes is organized so that men may dominate and women must submit and this relation is sexual-in fact, is sex." ${ }^{273}$ In this view, law is "an instrument of subordination." 274

Another main division, and the most relevant for situating my proposal, is between different voice feminism and social constructionist feminism. Different voice feminism posits that there are certain traits that are identified with women that should be recognized and taken seriously as specifically female characteristics. ${ }^{275}$ One such female characteristic that different voice feminists argue should be employed is an ethic of care. ${ }^{276}$ Robin West provides an explanation that makes clear the connection between the ethic of care and the biological realities of pregnancy:

Women are more empathic to the lives of others because women are physically tied to the lives of others in a way which men are not. Women's moral voice is one of responsibility, duty and care for others because women's material circumstance is one of responsibility, duty and care for those who are first physically attached, then physically dependent, and then emotionally interdependent. ${ }^{277}$

270. Patricia A. Cain, Feminist Legal Scholarship, 77 IowA L. REV. 19, 23 (1991).

271. Id.

272. See generally CATHERINE A. MACKINNON, FEMINISM UNMODIFIED (1987).

273. Id. at 3 .

274. Owen M. Fiss, The Law Regained, 74 CORNELL L. REV. 245, 251 (1989).

275. Jeanne L. Schroeder, Abduction from the Seraglio: Feminist Methodologies and the Logic of Imagination, 70 TEX. L. REV. 109, 120-22 (1991); see also Margaret Jane Radin, Reply: Please Be Careful with Cultural Feminism, 45 STAN. L. Rev. 1567, 1568 (1993) (using the synonymous term "cultural feminism").

276. Schroeder, supra note 275 , at 121-22.

277. Robin West, Jurisprudence and Gender, 55 U. CHI. L. REV. 1, 21 (1988). 
The different voice feminist today views the ethic of care as tied to pregnancy in a way that makes surrogacy problematic. ${ }^{278}$ By contrast, the social constructionist criticizes some aspects of different voice feminism as essentialist by depending on "false universals." 279

My proposal is grounded in the social constructionist's account of gender stereotypes. Twenty years ago, Ann Scales described the "enormous energies" spent by feminist legal scholars in "patching the cracks in the differences approach," and questioned whether there are any differences "sufficiently 'real' and permanent to demand social accommodation." $280 \mathrm{My}$ answer, for purposes of this proposal, is that there are not sufficiently permanent differences in parenting to justify different treatment by gender. I reject the contention that relationships with others, particularly children, are fundamentally different because of the biological processes of pregnancy, and argue that gender stereotyping is harmful even where it suggests a particular strength of women in parenting. ${ }^{281}$

The methodology for this analysis is thus a continuation of existing feminist legal methods. As chronicled by Katharine Bartlett, feminist legal methods include:

(1) identifying and challenging those elements of existing legal doctrine that leave out or disadvantage women and members of other excluded groups (asking the "woman question"); (2) reasoning from an ideal in which legal resolutions are pragmatic responses to concrete dilemmas rather than static choices between opposing, often mismatched perspectives (feminist practical reasoning); and (3) seeking insights and enhanced perspectives through collaborative or interactive engagements with others based upon personal experience and narrative (consciousnessraising). ${ }^{282}$

The "woman question" is further explained as "examining how the law fails to take into account the experiences and values that seem

278. See Jennifer S. Hendricks, Not of Woman Born: A Scientific Fantasy, 62 CASE W. RES. L. REV. 399, 441-45 (2011).

279. Cain, supra note 270 , at 28 . A related criticism not immediately germane for background purposes, but worth highlighting, is intersectionalism, which points out that gender essentialism that speaks of a universal woman's experience is inaccurate in that it depends upon the assumption "that a unitary, 'essential' women's experience can be isolated and described independently of race, class, sexual orientation, and other realities of experience." Angela P. Harris, Race and Essentialism in Feminist Legal Theory, 42 STAN. L. REV. 581, 585 (1990).

280. Ann C. Scales, The Emergence of Feminist Jurisprudence: An Essay, 95 YALE L.J. $1373,1374-75$ (1986).

281. See Levit, supra note 241 , at 1039 (describing issues of relational justice as "avoiding gender role stereotyping in both directions"); see also id. at 1054-55.

282. Katharine T. Bartlett, Feminist Legal Methods, 103 HARV. L. REv. 829, 831 (1990). 
more typical of women than of men, for whatever reason, or how existing legal standards and concepts might disadvantage women."283

Instead, I propose "asking the gender question," encompassing not only whether the law explicitly disadvantages women by failing to take their experiences into account, but also whether the law implicitly harms women by resting upon stereotypes. ${ }^{284}$ Asking the gender question can thus help to explain why even policies that seemingly honor women's contributions can be harmful. For example, Naomi Mezey and Cornelia T.L. Pillard recently chronicled the "new maternalism," which at first blush appears to be a celebration of the power of mothers in the political process by

revalidat[ing] motherhood as a source of pride and moral authority for women. . . . At bottom, however, new maternalist cultural assumptions reinforce the unequal consequences that flow from gendered family roles as they embrace and promote motherhood-and not parenthood or caregiving - as a value, an identity, an occupation, and a basis for political mobilization. ${ }^{285}$

Mezey and Pillard thus criticize the new maternalism as supporting "a mythic understanding of mothering that perpetuates deep and unnecessary inequalities between men and women and reinforces traditional understandings of the family." ${ }^{286}$

Asking the gender question of the current restrictions on the parental rights of unwed, biological fathers highlights a narrative of family law already chronicled in masculinity studies. Masculinity studies analyze masculinity as a social construction and alternative gender stereotype, ${ }^{287}$ particularly how one conception of masculinity becomes dominant (and thereby oppressive). ${ }^{288}$ Nancy Dowd, one of

283. Id. at 837 .

284. Adam Romero has previously proposed the use of "asking the gender question" and explicitly hypothesized that it might result in "advocating that women give up power to men in some realms, such as caretaking." Adam P. Romero, Book Review, Methodological Descriptions: "Feminist" and "Queer" Legal Theories, 19 YALE J.L. \& FEMINISM 227, 240 (2007) (reviewing JANET HALLEY, SPLIT DECISIONS: HOW AND WHY TO TAKE A BREAK FROM FEMINISM (2006)). Asking the gender question is thus similar to Darren Rosenblum's proposed "unsexing" of mothering as "a means to attack the linkage between biological sex ('biosex') and sex roles." Rosenblum, supra note 235, at 60. But see Martha Albertson Fineman, The Neutered Mother, 46 U. MIAMI L. REV. 653 (1992) (arguing that removing gender from the concept of "Mother" in the law is disingenuous and marginalizes biological differences and the women's perspective).

285. Naomi Mezey \& Cornelia T.L. Pillard, Against the New Maternalism, 18 MICH. J. GENDER \& L. 229, 233-34 (2012).

286. Id. at 234 .

287. See Ann C. McGinley, Ricci v. DeStefano: A Masculinities Theory Analysis, 33 HARV. J.L. \& GENDER 581, 585-86 (2010).

288. See Nancy E. Dowd, Asking the Man Question: Masculinities Analysis and Feminist Theory, 33 HARV. J.L. \& GENDER 415, 418-19 (2010); see also John M. Kang, The Burdens of Manliness, 33 HARV. J.L. \& GENDER 477, 487-91 (2010) (arguing that men are required to prove their masculinity through physical courage). 
the leading scholars writing in masculinity studies today, argues that understandings of masculinity that discourage fathers from nurturing children "pervade the law in a variety of ways that are harmful to men in their relationship to each other, to women, and to the state." 289

Masculinity studies can therefore highlight how stereotypes about fathering and manhood harm gender equality and generate proposals that will lead to greater parity in parental caretaking roles. Nancy Dowd, for example, proposed a revised UPA that recognizes a social father at birth. ${ }^{290} \mathrm{Her}$ social father is defined and identified through "the practice of nurture, either alone or in combination with other caretakers, as the sole or primary parent, or contributing as closely as possible to an equal amount of care giving in partnership with the other primary parent or parents. It is nonexclusive, cooperative parenting." 291 Dowd's proposal thus differs substantially from mine; it is based in functional theories ${ }^{292}$ and explicitly requires "an affirmative commitment to cooperative parenting with the mother," ${ }^{293}$ which I reject. What we share is a commitment to equalizing expectations and opportunities for both mothers and fathers to engage in meaningful caretaking of their children.

My proposal will be appealing to feminists who come from a social constructionist perspective and who view gender stereotypes as themselves harmful. ${ }^{294} \mathrm{I}$ argue that my proposal is feminist, in that it "adopts the view reflected by precedent that women and men both have the capacity to love a child deeply and that active engagement in caring for a child brings out this capacity." ${ }^{295}$

\section{Criticisms of Prebirth Labor}

There are at least two categories of concerns that might be raised in the wake of my arguments: first, objections to specific elements or consequences of prebirth parental labor as applied in the context of

289. Dowd, supra note 233, at 1322.

290. See Nancy E. Dowd, Parentage at Birth: Birthfathers and Social Fatherhood, 14 WM. \& MARY BILL RTS. J. 909, 931-38 (2006).

291. Dowd, supra note 233, at 1312.

292. See Dowd, supra note 290 , at $917-18$ \& n.55.

293. Id. at 913.

294. See, e.g., Marjorie M. Schultz, Book Review, Questioning Commodification, 85 CALIF. L. REV. 1841, 1855 (1997) (reviewing MARGARET JANE RADIN, CONTESTED COMMODI. ties: The Trouble with Trade in Sex, ChIldren, Body Parts, and Other Things (1996)) ("In assessing social damage associated with reproductive policy, the problem of men detaching from children is as serious as is treating women as baby machines. Furthermore, the damaging assumption that men can get paid for everything while women should act altruistically and be paid for almost nothing connected to their gender roles is very much alive and well.").

295. Hendricks, supra note 94 , at 432 . 
unwed biological fathers; and second, broader considerations relating to labor-based theories of intent.

I will discuss the more specific issues initially. First, there is potentially a class problem in evaluations of labor, in that many examples of prebirth labor - setting up a nursery in one's house, for example-cost money. ${ }^{296}$ To the extent that fathers with more money have more examples of prebirth labor open to them, this is a significant concern, particularly as low-income fathers already face structural barriers to parental engagement. ${ }^{297}$ It can be cabined, however, with a few observations. As with other evaluations of parental qualifications, any assessment of a father's prebirth labor should be evaluated with an eye to his individual circumstances. The absence of forms of labor that cost money should not be penalized where the father would be unable to afford them. Interestingly, although it seems intuitive that fathers with more financial resources would have more freedom to spend time with their children, evidence indicates that the reverse is true, possibly because lower-income parents who both work are forced to collaborate on caretaking duties due to economic pressures. ${ }^{298}$ It is clear, however, that economic issues are inadequately addressed for parents and families generally. ${ }^{299}$

Another question is whether recognizing the prebirth parental labor of unwed biological fathers would overcount such contributions: might this swing the pendulum from one extreme to the other, where checking a single book out of the library about child development is seen as equivalent in certain ways to the greater labor and costs accrued by the biological mother? A similar concern arose in the context of custody determinations. Because men typically do not perform caretaking labor, a presumption arises that the amount of caretaking necessary to rise to the notice of a court, or even to generate praise as an active father, is far less than half the overall burden. ${ }^{300}$ In the context of prebirth parental labor as used to vest parental rights, however, this concern is significantly different than in the custody context. In a custody determination, legal fathers are already recognized, with attendant obligations such as child support. Replicating parental caretaking in a way that overcounts the father's labor in many

296. Shari Motro provocatively linked the financial and relational aspects of parenthood in proposing that tax deductions be given to unmarried men who supported their pregnant lovers, which she termed "preglimony." See Shari Motro, Preglimony, 63 STAN. L. REV. 647 (2011).

297. See Laurie S. Kohn, Engaging Men as Fathers: The Courts, the Law, and FatherAbsence in Low-Income Families, 35 CARDOZO L. REV. 511, 524-25 (2013).

298. Dowd, supra note 233, at 1318.

299. Nancy E. Dowd, Essay, From Genes, Marriage and Money to Nurture: Redefining Fatherhood, 10 CARDOZO WOMEN'S L.J. 132, 135 (2003) ("Economic policy is foremost. Limited or no economic support means class-limited fatherhood.").

300. Rosenblum, supra note 235 , at 75. 
cases will reduce a child support obligation, raising serious strategic issues. The imposition of financial responsibility cuts the other way in the context of vesting parental status: an unwed biological father who actively claims parental status is voluntarily assuming what could be a significant child support obligation. A particularly devious soon-to-be father could conceivably claim parental status because he anticipated the biological mother pursuing child support from him and planned to minimize the burden by later making a custody claim to lower the obligation, but the links become so attenuated that the concern should diminish.

As a final proposal-specific concern, recognition of the parental status of an unwed biological father by incorporating prebirth parental labor could be viewed as preventing the acquisition of parental status by two parties. First, the Supreme Court cases dealing with unwed biological fathers generally deal with attempts to adopt the child in question by the child's existing stepfather. ${ }^{301}$ To the extent that unwed biological fathers are more able to assert their parental status, my proposal could correspondingly prevent adoption efforts by such stepfathers. One easy answer to this question is provided by the suggestion, discussed above, that more than two legal parents be recognized. In such a context, the functional parental status of a stepfather could be recognized without requiring termination of the parental status of the biological father. In the absence of such reforms, however, this is likely a vanishingly small criticism. Incorporating a labor-based understanding into the recognition of unwed biological fathers does not suddenly recognize every single unwed biological father as legal father. To the extent that some biological fathers do pursue parental status, this is likely to the benefit of the child in question, who now has support from both biological parents as well as potential stepparents.

Second, there is some history of procedures intended to benefit unwed biological fathers having perverse results. For example, in the early twenty-first century a majority of states created putative father registries: lists upon which a man places his name if he has a sexual encounter that might have resulted in the conception of a child. ${ }^{302}$ The registry is then used to notify the biological father of an adoption proceeding involving the child. ${ }^{303}$ In theory, the existence of such registries provided men with an opportunity to timely assert parental rights. In practice, timely placing one's name on a putative father registry - of which most men continue to be unaware--became the

301. See, e.g., Lehr v. Robertson, 463 U.S. 248 (1983); Caban v. Mohammed, 441 U.S. 380 (1979); Quilloin v. Walcott, 434 U.S. 246 (1978).

302. See Amy M. Clark, How Putative Father Registries Foster the Best Interest of the Child Standard, 1 APPALACHIAN J.L. 57, 58, 62 (2002).

303. Id. at 58 . 
first requirement to assert parental status, and if a man failed to do so it foreclosed claims that he might have otherwise had. ${ }^{304}$ In the same form, might acknowledgment of prebirth labor unintentionally harm men who do not know either about the law or even about the existence of the child? I argue that it does not: the absence of prebirth parental labor should not, as current doctrine requires, foreclose recognition of a substantial relationship with the child. Prebirth parental labor cannot be compared, therefore, to putative father registries or other formal requirements.

A second set of concerns arise from broader objections to intent as a parentage rule. In this context, the strength of labor-based theories of intent becomes clear. One common concern with intent is that if intent becomes a single rule upon which parental status turns, people who currently have parentage imposed upon them, such as unwed biological fathers upon whom child support obligations are imposed, will evade such responsibilities by simply claiming they did not intend to be a parent. A common response from proponents of intent is to argue that intent should be a path into parenthood, but not a way to evade parenthood. ${ }^{305}$ Labor makes this clearer: no one is able to evade parental responsibilities by simply refusing to do them. Labor thus provides a more tangible example of how intent-based rules can supplement, rather than replace, other rules such as biological relationships.

Another worry, discussed above, is that intent can be manipulated by strategic actors. ${ }^{306}$ Again, because labor is a more tangible commitment than mere expression of intent, it is a larger burden for a potential parent seeking to exploit parental rules. Furthermore, status as legal parent does not guarantee greater custody or visitation rights or a lower child support burden: such decisions would still be made using the standard of the best interests of the child, as they are currently. This individualized evaluation has been settled upon in part because it should identify strategic parents who ask for custody solely as a litigation tactic in custody proceedings, and should serve the same purpose here. Finally, even intent as demonstrated through labor is more difficult to evaluate than genetic connection or marital presumptions, as it is not a bright line rule. Nancy Dowd pointed out, however, that the best interests standard is similarly individual-

304. Timothy L. Arcaro, No More Secret Adoptions: Providing Unwed Biological Fathers with Actual Notice of the Florida Putative Father Registry, 37 CAP. U. L. REV. 449, 451-52 (2008). Jonathan Lehr, for example, had failed to file with the New York putative father registry, which foreclosed his right to assert a due process or equal protection violation. Lehr v. Robertson, 463 U.S. 248, 264-65 (1983).

305. Melanie Jacobs goes further, to argue that the obligations and rights of parentage should be split in some circumstances between multiple people. See Jacobs, My Two Dads, supra note 90 , at 813 .

306. See supra Part IV.A. 
ized - and while it is undoubtedly more burdensome than a bright line custody rule such as the tender years doctrine, the additional work is justified by results that are significantly better for children. ${ }^{307}$ A similar calculus applies here.

\section{CONCLUSION}

Parentage is often colloquially described as eighteen years of hard labor. Although intended as a joke, such observations have a basis in fact: parentage is increasingly understood as created by labor, in addition to remnants of theories of bodily unity based in genetic connections. Rigorous analysis of a labor-based theory of parentage demonstrates deficiencies in the current regime as well as points a way toward reforms that will not only have tangible benefits for children and parents, but also create a more unified body of parentage law.

307. See Dowd, supra note 290 , at 940 . 